\title{
Cave shrimps Troglocaris s. str. (Dormitzer, 1853), taxonomic revision and description of new taxa after phylogenetic and morphometric studies
}

\author{
JURE JUGOVIC ${ }^{1,2 *}$, BRANKO JALŽIĆ ${ }^{3}$, SIMONA PREVORČNIK $^{4} \&$ BORIS SKET $^{5}$ \\ ${ }^{1,4,5}$ Univerza v Ljubljani, Biotehniška fakulteta, Oddelek za biologijo, Večna pot 111, 1000 Ljubljana, Slovenia. \\ ${ }^{2}$ Univerza na Primorskem, Znanstveno raziskovalno središče, Garibaldijeva 1, 6000 Koper, Slovenia \& Univerza na Primorskem, \\ Fakulteta za matematiko, naravoslovje in informacijske tehnologije, Glagoljaška 8, 6000 Koper \\ ${ }^{3}$ Hrvatski prirodoslovni muzej, Demetrova 1, 10000 Zagreb, Croatia. \\ E-mail addresses: ${ }^{1}$ jure.jugovic@bf.uni-lj.si; jure.jugovic@zrs.upr.si; ${ }^{3}$ branko.jalzic@hpm.hr; ${ }^{4}$ simona.prevorcnik@bf.uni-lj.si; ${ }^{5}$ \\ boris.sket@bf.uni-lj.si \\ * Corresponding author
}

\begin{abstract}
Within the Dinaric genus Troglocaris cave shrimps from the subgenus Troglocaris s. str. (Dormitzer, 1853) (Crustacea: Decapoda: Atyidae), have the widest distribution area. The recent molecular analyses have revealed significant, cryptic diversity in the subgenus. The aim of the subsequent detailed morphometric analyses was the provision of the appropriate diagnosable characters for the discovered lineages, i.e. taking care of their taxonomical visibility. We herein designate a neotype and provide a detailed description for the polytipic type species of the genus T. (T.) anophthalmus (Kollar, 1848), to enable its morphological distinction from the erroneously described T. (T.) planinensis Birštejn, 1948. Considering a combination of morphological, geographical and molecular data, we describe four new subspecies: T. (T.) a. ocellata ssp. nov., T. (T.) a. periadriatica ssp. nov., T. (T.) a. legovici ssp. nov. and T. (T.) a. sontica ssp. nov., apart from the extant $T$. (T.) a. intermedia Babić, 1922. Due to a considerable morphological variability and no easily observable diagnostic morphological characters, the GenBank accession numbers for the COI gene are added in all mentioned taxa.
\end{abstract}

Key words: Atyidae, phylogeny, subterranean, morphology, taxonomy

\section{Introduction}

Although only an integration of all biological disciplines can promote biological research at the tempo set by biodiversity crisis (Whitfield 2007), the morphology-based alpha taxonomy (MOBAT) remains the most important discipline, providing the accessible data-set for assigning taxonomically valid names on the basis of name-bearing specimens. Many "cryptic" species or species with an "overlooked diversity" remain taxonomically invisible, as badly under-resourced MOBAT cannot keep pace with their discovery. The MOBAT is essential and should be promoted if the promise of the profound implications for the evolutionary theory, biogeography and conservation planning is to be realised (Schlick-Steiner et al. 2007).

The freshwater cave dwelling shrimp Troglocaris anophthalmus (Kollar 1848) is among Dinaric largest and most distinctive cave invertebrates. Despite of intensive research of its taxonomy (e.g. Kollar 1848; Dormitzer 1853; Babić 1922; Holthuis 1956), reproduction, ontogeny (Matjašič 1958, Juberthie Jupeau 1974, 1975), as well as ecology (Gottstein-Matočec 2003), the taxonomy of the genus has remained unresolved for a century or longer.

An initial molecular analysis of numerous European cave shrimp populations to solve a biogeographical enigma of Troglocaris, was conducted by Zakšek et al. (2007). In 54 specimens from three known disjunct centres of the genus distribution, three genetic markers were used for a reconstruction of its phylogeny: mitochondrial cytochrome oxydase subunit I mtDNA (COI, 610 base pairs), 16S rDNA (472 bp) and nuclear ITS2 rDNA (836 bp). The genus was found to be polyphyletic. The results promoted an a posteriori redefinition of taxa at different levels (Sket \& Zakšek 2009). The novel genus Gallocaris Sket et Zakšek, 2009, was erected for the French taxon Troglocaris schmidti inermis Fage, 1937, related to the genus Dugastella Bouvier. Additionally, four new Dinaric 
species were recognized, three of them belonging to the subgenus Spelaeocaris Matjašič, 1956: T. (S.) prasence, T. (S.) kapelana and T. (S.) neglecta all Sket et Zakšek, 2009. Within the subgenus Troglocaris (= Troglocaris s. str.) only T. (T.) bosnica Sket et Zakšek, 2009, was morphologically and molecularly distinct enough to be described. All other populations of Troglocaris s. str. were assigned to Troglocaris aggr. anophthalmus. Further phylogenetic analyses (Zakšek et al. 2009) tested T. aggr. anophthalmus for a possible cryptic diversity and/or unrecognized evolutionary processes. The phylogeographical procedures showed that this aggregate is composed of four major monophyletic, geographically defined phylogroups: W-Slovenian, E-Slovenian, Adriatic, and Soča phylogroups. Authors argued that phylogroups could be treated as species as they are in agreement with all four aspects of genealogical concordance species concepts (sensu Avise 2000). Syntopy of the W-Slovenian and the putative fifth, i. e. Istra, phylogroups confirmed the status of biological species (sensu Mayr 1970) of the former phylogroup. It also indicated the same possibility for the putative phylogroup in spite of its much lower COI genetic distance (Zakšek et al. 2009). However, it has remained unresolved whether the Istra putative phylogroup represents a biological species per se or as a part of the rest of $T$. aggr. anophthalmus, excluding W-Slovenian phylogroup. In the same study, a detailed sampling also recovered a further split of the E-Slo phylogroup into E-Slo1 and E-Slo2 subgroups, which were geographically associated.

The phylogenetic framework published by Zakšek et al. (2007, 2009) provided a solid basis for the detailed morphometric studies (Jugovic et al., 2010a, 2011). Only the adult animals were included in the analyses to exclude main sources of ontogenetic variation. Beside 71 metric also 17 meristic characters were recorded (all listed in Jugovic et al., 2011), describing body proportions and elaboration of cuticular structures. Additionally, eye pigmentation, presence of supraorbital, antennal and pterygostomial spine, as well as presence of exopodites on pereopod V were considered. The descriptions, as well as the taxonomic decisions presented herein follow the results of discriminant function analysis (Jugovic et al. 2011) conducted in accordance with Zakšek et al. (2009: p. 933-934, Table 1; see also Appendix C) molecular analysis.

In this paper we are trying to imply the biological species concept (Mayr 1970) to delimit some taxa within $T$. aggr. anophthalmus. Presently, the inappropriate morphological characters used for the recognition of three taxa within the aggregate: T. (T.) a. anophthalmus (Kollar, 1848), T. (T.) a. intermedia Babič, 1922, and T. (T.) planinensis Birštejn, 1948 prevent their proper identification (Sket \& Zakšek 2009). Apart from T. (T.) planinensis (= W-Slo phylogroup), the aggregate consists of (Sket \& Zakšek 2009; Zakšek et al. 2009, Figure 1): (1) T. (T.) anophthalmus anophthalmus (= E-Slo1 subgroup and geographical group), (2) T. (T.) anophthalmus intermedia (= a subspecies that is molecularly nested within E-Slo phylogroup), (3) T. (T.) anophthalmus - Bela Krajina (= ESlo2 subgroup and geographical group), (4) T. (T.) anophthalmus - Adriatic (= Adriatic phylogroup and geographical group), and (5) T. (T.) anophthalmus - Soča (= Soča phylogroup and geographical group), and (6) $T$. (T.) anophthalmus - Istra (= Istra putative phylogroup, according to ITS2 marker).

Since (except for T. (T.) planinensis = W-Slo phylogroup) the recognition of the above listed groups of populations as separate biological species would require information on their mating potential (reproductive isolation), we are designating them as subspecies of $T$. (T.) anophthalmus. We are considering multiple samples for each subspecies designation, thus trying to avoid the negligence of morphological variability present in Birštejn (1948) and Kollar (1848). Although the consistency of T. (T.) anophthalmus group from Istra (= Istra putative phylogroup) was not clearly supported by the mtDNA genetic marker, we believe a description of a subspecies is legitimate: the group is morphologically and genetically variable, its consistency is supported by a nuclear marker (we use it as a diagnostic character).

\section{Materials and methods}

Based on (1) the molecular analyses which indicated genetic isolation of several populations within $T$. aggr. anophthalmus (see the list of references in the Introduction section), (2) the subsequent detailed morphometric analyses were conducted, confirming the morphological distinctiveness of the identified phylogroups (see chapter »Morphometric analysis«); and (3) the description of several taxa (species and subspecies) were enabled. Although the morphological differences are minute, identification of taxa is possible when all descriptives (i.e. morphological, genetic and ecological evidence) are considered simultaneously (see chapters »Abbreviations and organisation of the text« and »Taxonomic descriptions «). 


\title{
Morphometric analysis
}

The majority of specimens are deposited in the Zoological collection of the Oddelek za biologijo, Biotehniška fakulteta, Univerza v Ljubljani, Ljubljana (OBBFUL), Slovenia. Specimens deposited elsewhere are specified in the Results section (see also Appendix C). Altogether, 80 samples comprising over 580 specimens of $T$. aggr. anophthalmus from all known molecular phylogroups recognized by Zakšek et al. (2009; phylogroups/subgroups listed in the Introduction section) were surveyed, each specimen acquiring a unique voucher number (Appendix C). Besides morphometric data from Jugovic et al. (2011), the newly studied samples mainly collected in Istra and from the type localities were used for the herein descriptions (see Appendix C), following the same methodology as indicated in Jugovic et al. (2011). As some sexually dimorphic characters were disclosed lately, separate discriminant function analyses for adult males and females were conducted (Appendix A). Such analyses enabled the inclusion of both, sexually non-dimorphic (as in Jugovic et al. 2011), as well as of sexually dimorphic characters.

\section{Abbreviations and organisation of the text}

The abbreviation "CL" is consistently used for a carapace length in the descriptions while all other abbreviations are only provided to warrant consistency with the Figure 5 and Appendix B (this paper) and Appendices from Jugovic et al. (2011). They are defined by their first appearance in the text. The rostral dentition formula '(X+Y)/Z' denotes number of teeth dorsally on rostrum and carapace by the number of teeth ventrally on rostrum.

The anterior spine-like projections on the carapace are called spines (supra-, suborbital spines; see Figure 2B), following a traditional nomenclature. The spiniform setae on the telson are denominated in accordance with Sket \& Zakšek (2009); three pairs of dorsal spiniform setae are present throughout this group of taxa, but the distal pair has been considered as a part of the spiniform setae row and has been placed on the distolateral corners of the telson (see Figure 2Tel). Pereopod III-VII length is given as the sum of articles 3-7 lengths (articles 3-6 in pereopods I-II), due to the prevalent loss (damaging) of basal articles during section. Roman numerals are used to denote successive body metameres and appendages, whilst the Arabic numerals denote articles within the appendages. The term 'comb-like' in connection with the pereopod dactyl (article 7) refers to a dense row of spiniform setae along its inner margin (as in Figure $4 \mathrm{PpV}$ - see the enlarged part).

Since the morphological differences among taxa are minute, the full description of all investigated characters is provided only for $T$. (T.) anophthalmus anophthalmus (= E-Slo1 subgroup). A single reported value is given for the male neotype while a range of values [in parentheses] refers to all other males from the subspecies' collection. The descriptions for other taxa (denoted as »differential descriptions « in the text), however, comprise exclusively specifications for the most discriminative characters. The comparison of these characters for six phylogroups of Troglocaris s. str is shown in Figure 5. A differential description of T. (T.) anophthalmus anophthalmus is added for practical reasons (see Appendix D). In the differential descriptions of males and females the arithmetic mean, standard deviation, minimum and maximum [in parentheses] are given for each character, considering all specimens of the taxon/phylogroup. In the description of $T$. (T.) anophthalmus anophthalmus females, the same values as for differential descriptions are used. In the Istra phylogroup females, only some morphometric characters are presented (see Appendix B) owing to small sample size and rather damaged animals. For the comparison of the most discriminative characters, see Appendix B. One should be aware that T. (T.) anophthalmus anophthalmus, $T$. (T.) anophthalmus intermedia and T. (T.) anophthalmus ocellata ssp. nov., were all comprised within the E-Slo phylogroup (see Sket \& Zakšek 2009), since the lack of the molecular data prevented their further recognition.

\section{Results}

\section{Taxonomic descriptions}

\author{
Family Atyidae De Haan \\ Subfamily Paratyinae Holthuis \\ Genus Troglocaris Dormitzer, 1853
}




\section{Subgenus Troglocaris (Troglocaris) Dormitzer, 1853 \\ Troglocaris (Troglocaris) anophthalmus anophthalmus (Kollar, 1848)}

Synonymy: Palaemon anophthalmus Kollar, 1848; Troglocaris schmidtii Dormitzer, 1853; see also Holthuis (1956); Troglocaris (Troglocaris) - the E-Slo1 subgroup Zakšek et al., 2009

Type locality: Slovenia, Dobrepolje, cave Kompoljska jama.

Material examined: Neotype: adult male (TA965), CL $7.6 \mathrm{~mm}$, Kompoljska jama, Kompolje, Videm-Dobrepolje, Slovenia, $45^{\circ} 47^{\prime} 58.23^{\prime \prime} \mathrm{N}, 14^{\circ} 43^{\prime} 51.39^{\prime \prime} \mathrm{E}, 3^{\text {rd }}$ September 2009, collected by J. Jugovic, specimen partly dissected, preserved in $70 \%$ ethanol.

Other specimens from the neotype locality: Males: adult male (TA966; preserved in $96 \%$ ethanol at $-20^{\circ} \mathrm{C}$ ), $7.5 \mathrm{~mm}$; adult male (TA977; preserved in $96 \%$ ethanol at $-20^{\circ} \mathrm{C}$ ), $6.5 \mathrm{~mm}$; same data as neotype. Females: 8 adult females, TA975 (CL $8.4 \mathrm{~mm}$ ); TA976 (CL $7.4 \mathrm{~mm})$; TA978 (CL $8.5 \mathrm{~mm}$ ); TA979 (CL $7.1 \mathrm{~mm})$; TA980 (CL $7.8 \mathrm{~mm})$; TA981 (CL $7.3 \mathrm{~mm}$ ); TA982 $(6.9 \mathrm{~mm})$ (all preserved in $70 \%$ ethanol); TA989 (CL $7.3 \mathrm{~mm})$ (preserved in $96 \%$ ethanol at $\left.-20^{\circ} \mathrm{C}\right)$; same data as neotype.

Other specimens examined: over 60 specimens from 11 samples (Figure 1, Appendix C1). Males, CL 4.7-8.3 mm. Females, CL 5.8-9.0 mm. Voucher numbers and GenBank identification numbers for COI gene are in Appendix C1.

Diagnosis: Subspecies of $T$. (T.) anophthalmus with completely reduced eye and body pigmentation. Rostrum length variable, when rostrum longer than $45 \%$ of CL, dorsal margin usually curved upwards, ventral margin with 7 teeth or less. Antenna I article 3 length usually more than $1 / 2$ of article 2 length. Pereopod III article 4 usually with three or less spiniform setae along inferior margin and at inferodistal angle, article 6 weakly or strongly curved in adult males. Pereopod V only exceptionally with exopodite. Fully mature males with no or with a single retinacular hook on appendix interna of pleopod I endopodite. Medial margin of pleopod I endopodite with short spiniform setae.

Description of male neotype and other [values in parentheses, if different] male material (partly after Fabjan 2001): Body and eye pigmentation completely reduced. CL $7.6 \mathrm{~mm}$ [5.3-7.6 mm]. Carapace (Figure 2B) surface smooth, with supraorbital and suborbital spines only. Anterolateral carapace angle rounded, without pterygostomial angle. Transversal crest posteriorly on the carapace. Rostrum length $59 \%$ [32-78 \%] of CL, shape sigmoidal [various], with $25+7 / 2$ teeth [12-31+4-11/0-7]. Teeth on carapace along $17 \%$ [14-25\%] of CL. Abdominal somites smooth. Pleonite V length $56 \%$ [45-60\%] of pleonite VI length. Telson (Figure 1Tel) length $47 \%$ [40-64 $\%$ ] of CL and $87 \%$ [85-109\%] of pleonite VI length. Telson elongated rectangular, distal margin width $66 \%$ [48-80\%] of proximal margin width, the former $13 \%$ [10-16\%] of CL. Dorsal surface with 3 pairs of dorsolateral spiniform setae [exceptionally 4 setae on one margin], at $0.60,0.74$ and 0.94 of telson length. Rather rounded distal border with 11 [9-14] strong spiniform setae; both distolateral setae approximately 3 times longer, all other 2 times longer than dorsolateral spiniform setae.

Antenna I (Figure 2AI) peduncle length $52 \%$ [46-61\%] of CL. Peduncular article 1 about 1.5 [1.3-1.7] times as long as article 2, the latter 1.6 [1.5-2.0] times as long as article 3. Article 1 with nearly straight mesial margin with setose distal part; lateral stylocerite with broad base and slender, acute tip, its length $42 \%$ [37-45\%] of peduncle length and approximately $80 \%$ of article 1 length; distolateral lobe sharply pointed, its length $13 \%$ [13-18\%] of peduncle length. Article 2 length approximately $83 \%$ of article 1 length, mesial and lateral margins setose. Article 3 length approximately $41 \%$ of article 1 length. Upper flagellum uniramous, lower flagellum slender, lengths of both flagella rather exceeding $200 \%$ of CL.

Antenna II (Figure 2AII) with robust basicerite. Peduncle length $34 \%$ [32-43\%] of CL. Scaphocerite 2.7 [2.6-3.2] times as long as wide, approximately 1.7 times [1.4-1.7] as long as peduncle, its length 55\% [51-63\%] of CL, distally broad, ovally produced, lateral margin nearly straight with stout distolateral tooth. Tooth length 10 $\%$ [9-13\%] of scaphocerite length. Scaphocerite mesial, distal and distolateral margins fringed with dense row of plumose setae. Flagella length rather exceeding $200 \%$ of CL.

Mandibula with rather robust corpus, with small group of plumose setae on lateral margin. Without palp. Mandibular pars incisiva (incisor process; Figure 3Md) stout, tapering distally, distal margin of 3 [3-6] teeth of different size. Teeth number on left and right mandible often different. Pars molaris stout, U-shaped with triturative surface and numerous short simple marginal setae. Spine row of scarce serrate setae traversing to dense pappose setae.

Left maxilla I (Figure 3MxI(1)) palp truncated, with one long plumose seta at interodistal angle and one [1-2] stout spiniform subdistal seta. Right maxilla I palp (Figure 3MxI(r)) without plumose seta. Rectilinear outer margin 
of upper lacinia (basipodial endite) with numerous short strong cuspidate setae, curvilinear inner margin and ventral surface with plumose setation. Lower lacinia (coxal endite) well developed, semicircular; outer margin with dense plumose and serrate setation, submedial line with five rows of shorter pappose and some simple setae. Outer part with sparse group of pappose setae.

Maxilla II (Figure 3MxII) with slender, simple, tapering palp with one simple seta distally. Basipodial endite bilobed; upper lobe subrhomboidal, margins with dense plumose and serrate setation, ventral surface with group of sparse plumose setae. Lower lobe with almost rectilinear outer margin, fringed with densely packed plumose and serrate setae; sparse simple setae are present all over its surface. Coxal endite fan-like, with dense plumose setae along distal margin and scarce plumose setae subdistally. Scaphognatite well developed, broad, margin fringed with plumose setae, anterior lobe large, posterior lobe narrower, subtriangular, with group of plumose setae on lower distal part.

Maxilliped I (Figure 3MxpI) palp clubby, flat distal margin with several plumose setae. Epipodite poorly developed, bilobed. Basipodial endite approximately 2.5 times longer than coxal endite, distal margin and mesial surface with dense rows of long plumose setae, almost rectilinear outer margin with row of shorter papulose setae with scale-like setules. Coxal endite poorly developed, with short serrate and longer plumose setae along outer margin. Exopodite with large caridean lobe approximately 2 times longer than flagellum. Lobe and flagellar margins and lobe ventral surface with plumose setation.

Maxilliped II (Figure 3MxpII) with well developed endopodite. Dactylopropodus broad, with long plumose setae on upper superior margin, densely packed longer pappose and shorter serrate setae along almost rectilinear lower superior margin and some long submarginal plumose setae. Exopodite with well developed flagellum, with plumose distal setae and serrate proximal setae. Well developed comb-like podobranchium with approximately 8 branches.

Maxilliped III (Figure 3MxpIII) with slender endopod, its length $89 \%$ [84-105\%] of CL. Ischiomerus well separated from basis, rather curved, about 5.5 times as long as wide, with sparse pappose setae proximally on superior margin. Penultimate article slender, about 8.2 times as long as wide and 1.1 times ischiomeral length, with spiniform submarginal setae on mesial surface and few long pappose setae at distosuperior angle. Terminal article (dactylopropodus) about 11.5 times as long as wide and 1.3 times ischiomeral length, tapering distally, with strong apical dactylopropodal spine (claw). Distal $1 / 3$ of inferior margin with approximately 9 subequal spiniform setae, proximal $2 / 3$ of mesial surface and superior submarginal surface with transverse series of serrate setae. Exopodite tip reaching beyond ischiomeral distal tip, robust flagellum with serrate proximal setae and long plumose distal setae. Coxa with larger, well developed arthrobranchium upper and smaller, weakly developed (frequently damaged by section) lower arthrobranchium.

Pereopod I (Figure 4PpI) length from base of article 3 (ischium) to apex of article 6 (propodus, unmovable finger of chela) $57 \%$ [53-67\%] of CL. Length relations of above articles (in percentages of pereopod I length): 15 $\%$ [11-16\%]: $22 \%$ [22-27\%]: $33 \%$ [27-33\%]: $30 \%$ [29-36\%]. Chela with palm subcylindrical, slightly compressed, fingers with dense tuft of longer pappose and shorter serrate setae apically. Within tufts also shorter setae rounded distally (Figure 4PpIfin). Article 6 maximal length $22 \%$ [21-26\%] of CL, its length 2.2 [1.9-3.1] times its width. Chela palm well developed, its basal bulge length approximately $23 \%$ [13-26\%] of article 6 maximal length. Article 7 (dactylus, movable finger) length $49 \%$ [49-66\%] of article 6 maximal length. Exopodite with serrate basal setae and plumose distal setae, little overreaching distal end of article 4 (merus).

Pereopod II (Figure 4PpII) longer and thinner than pereopod I, its length (given as in pereopod I) $75 \%$ [69-88 $\%$ ] of CL. Length relations of above articles (given as in pereopod I): $17 \%$ [14-19\%]: $24 \%$ [23-28 \%]: $34 \%$ [31-35\%]: $25 \%$ [24-29\%]. Chela with palm subcylindrical, slightly compressed, fingers with dense tuft of longer pappose and shorter serrate setae apically. Within tufts also shorter, distally rounded setae (as shown for pereopod I on Figure 2PpIfin). Article 6 maximal length $23 \%$ [21-27 \%] of CL, its length 2.4 [2.0-3.6] times its width. Chela palm well developed, its basal bulge length approximately $21 \%$ [11-22\%] of article 6 maximal length. Article 7 (dactylus, movable finger) length $60 \%$ [48-66\%] article 6 maximal length. Exopodite with serrate basal setae and plumose distal setae, reaching distal end of article 4 (merus).

Pereopod III (Figure 4PpIII) length from base of article 3 (ischium) to apex of article 7 (dactylus) $153 \%$ [148-205\%] of CL. Length relations of above articles (in percentages of pereopod III length): $9 \%$ [7-10\%]: $34 \%$ [31-36\%]: $18 \%$ [17-20\%]: $31 \%$ [28-33\%]: $8 \%$ [5-12\%]. In fully mature males article 7 inferior margin with 


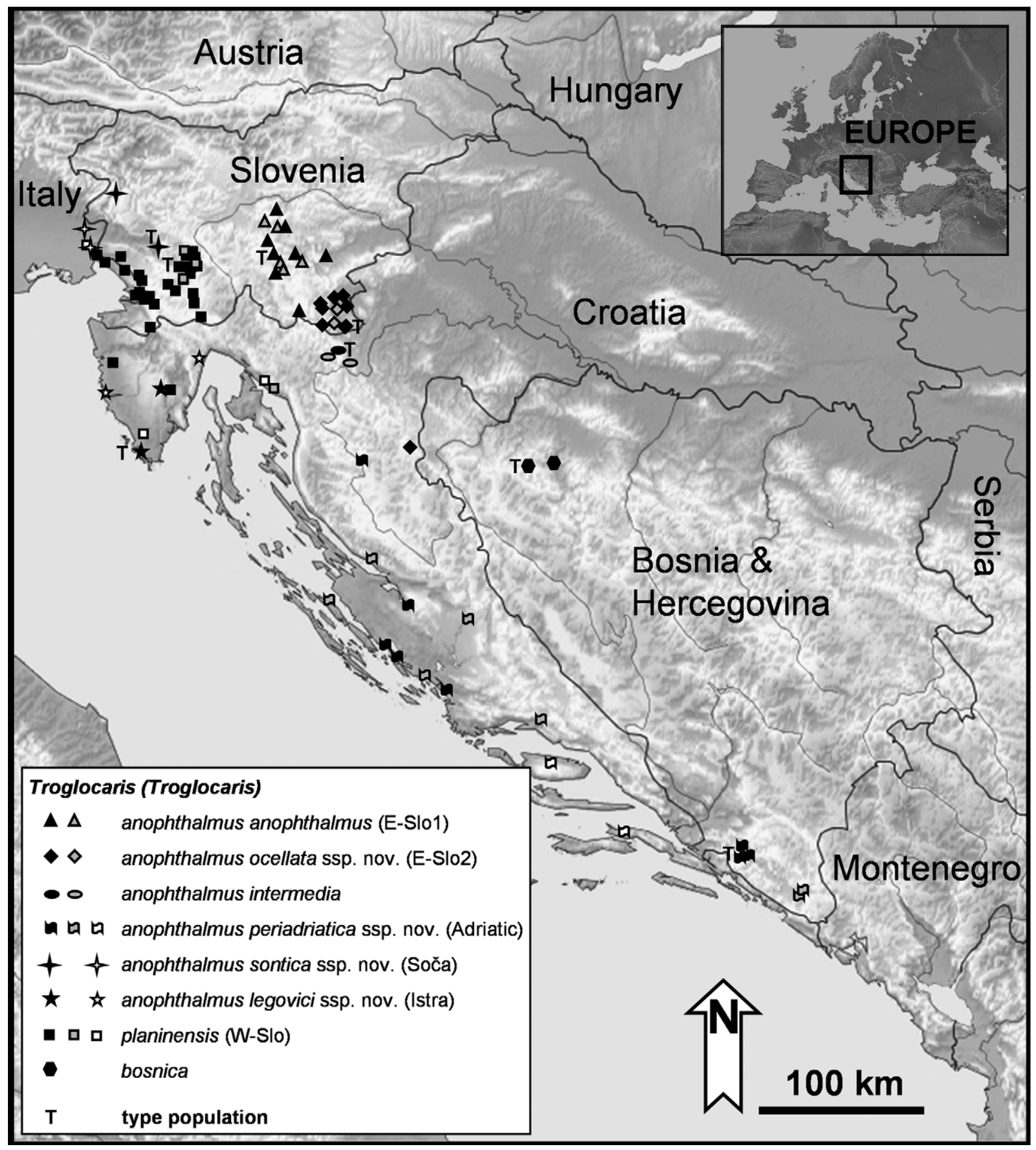

FIGURE 1. Distribution map of eight taxa of the subgenus Troglocaris s. str., with phylogroup/subgroup designation (in brackets, as in Zakšek et al. 2009). Different symbols denote taxa, their coloration denotes method of the analysis: black molecular and morphometric analysis; grey - morphometric analysis; white - molecular analysis.

17 [8-40] spiniform setae in two, proximally densely and distally rarely set groups. Article 6 of mature males slightly curved, $13 \%$ [12-20\%] of article 6 length differentiated (i.e. article distally widened, with a group of numerous spiniform setae). Articles 5 and 4 bear 1 and 3 [1-4] large spiniform setae on mesial surfaces, respectively. Article 3 bears 1 smaller [0-1] spiniform seta on mesial surface. Exopodite well developed, with basal serrate setae and plumose distal setae, reaching approximately second half of article 4 (merus). Pereopod IV similar to pereopod III. 
Pereopod V (Figure 4PpV) length $157 \%$ [142-171\%] of CL. Length relations of its articles (in percentages of pereopod V length): $8.5 \%$ [8-9\%]: $30 \%$ [28-30\%]: $18 \%$ [16-19\%]: $36 \%$ [35-38\%]: $7.5 \%$ [7-9\%], the latter with 43 [37-54] equally long spiniform setae, formatting a comb-like article 7. Articles 5 and 4 bear 1 and 2 [1-3] large spiniform setae on mesial surfaces, respectively. Article 3 bears no [0 (exceptionally)-1] spiniform setae on mesial surface.

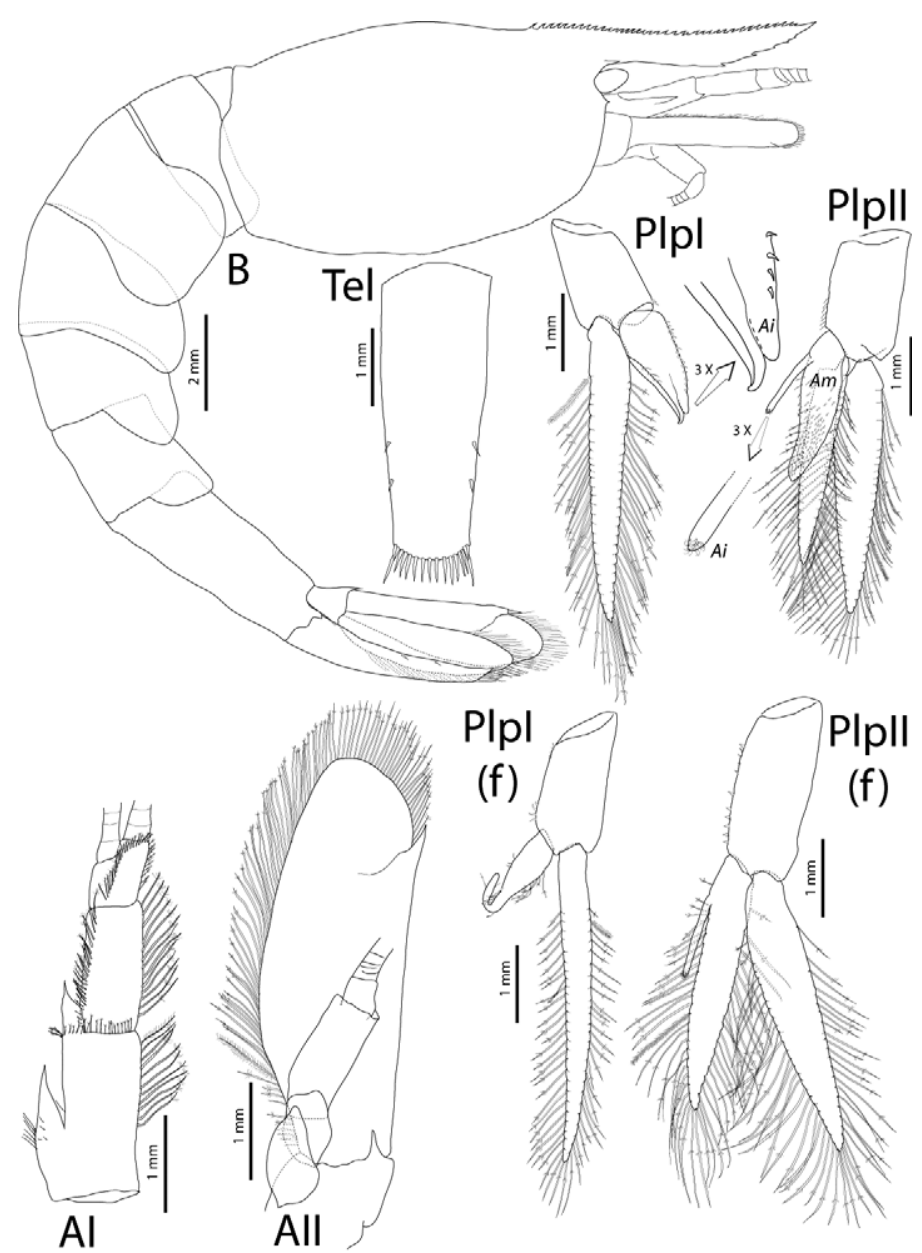

FIGURE 2. Troglocaris (Troglocaris) anophthalmus, Kompoljska jama, Kompolje, Videm-Dobrepolje, male (TA966), CL $7.5 \mathrm{~mm}$ : B, body, appendages (except antennae I-II and uropods) omitted, lateral view; Tel, telson, dorsal view; PlpI, left pleopod I; PlpII, left pleopod II; AI, left antenna I; AII, left antenna II. Female (TA975), CL 8.4 mm: PlpI(f), left pleopod I, PlpII(f), left pleopod II. Ai, appendix interna; Am, appendix masculina. Enlarged parts of the structures are indicated by arrows and their magnifications.

Pereopods I-IV with pleurobranchia, epipodites and exopodites. Pereopod V with pleurobranchium, without epipodite, exceptionally with exopodite - if developed, exopodite short, not/barely exceeding pereopod article 2 (basis) in length. All pereopods with setobranchia.

Pleopod I (Figure 2PlpI) endopodite well developed, with wide basis, tapering apex and slightly bent shallow groove on outer subdistal part. Endopodite length $19 \%$ [17-25\%] of CL and 38 \% [34-46\%] of exopodite length. Outer margin with 17 [17-33] spiniform setae. Appendix interna with no [0-1] retinacular hooks distally, not exceeding lamina in length. Exopodite with plumose setae along margins.

Pleopod II (Figure 2PlpII) with well developed shield-like appendix masculina, with numerous spiniform setae on medial and subdistal surface; its length $24 \%$ [24-35\%] of CL and $63 \%$ [62-73\%] of endopodite length. Appendix masculina 2.1 [2.1-3.3] times longer than appendix interna, the latter with 15 [3-23] retinacular hooks apically. Exopodite 1.2 [1.1-1.3] times longer than endopodite. Endopodite and exopodite lengths 39\% [37-51\%] and $44 \%$ [43-60\%] of CL, respectively; their inner and outer margins fringed with plumose setae.

Uropod (Figure 4U) exopodite overreaching tip of endopodite, its width $33 \%$ [29-34 \%] of length, its length $60 \%$ [50-71\%] of CL. Exopodite lateral margin almost rectilinear and without setae proximal to distolateral tooth, 
other margins fringed with plumose setae, sparse setae also subterminally on surface. Diaeresis with 1 [exceptionally 2] movable stout spiniform seta. Endopodite length about 0.9 exopodite length, with plumose setae along margins.
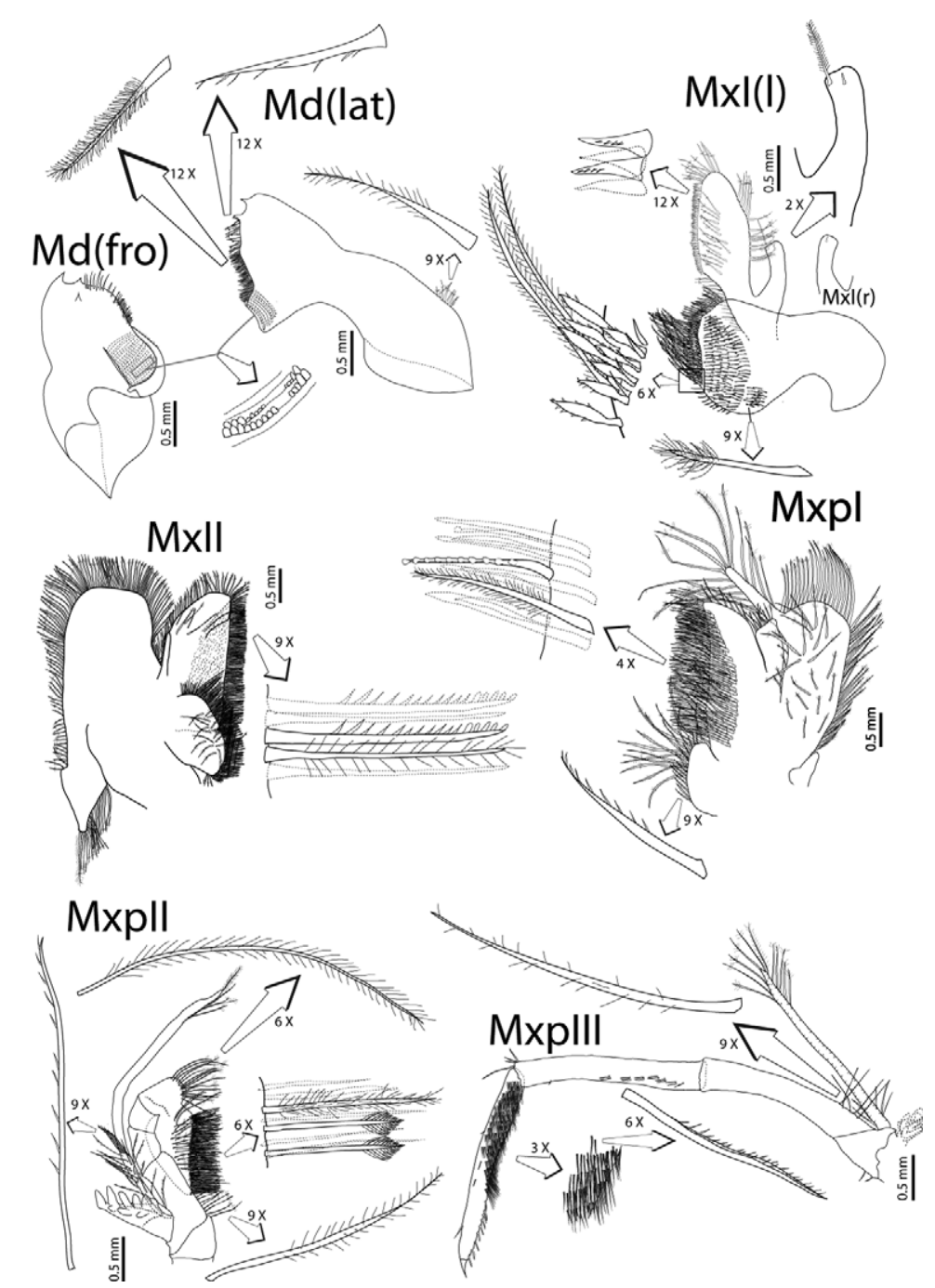

FIGURE 3. Troglocaris (Troglocaris) anophthalmus, Kompoljska jama, Kompolje, Videm-Dobrepolje, neoparatype male (TA966), CL 7.5 mm: MxpII, left maxilliped II; MxpIII, left maxilliped III. Neoallotype female (TA975), CL 8.4 mm: Md, left mandible: fro - frontal view, lat - lateral view; MxI(l), left maxilla I, MxI(r), palp of right maxilla I, MxII, left maxilla II, MxpI, left maxilliped I. Enlarged parts of the structures are indicated by arrows and their magnifications.

Description of females (partly after Fabjan 2001; average values presented): CL $7.4 \pm 0.8 \mathrm{~mm}$ [5.8-9.0 mm], significantly longer than in males (t-test, $\mathrm{p}<0.05$ ).

Pereopods III-IV subsimilar, not differentiated. Pereopod III (Figure 4PpIII(f)) length from base of article 3 (ischium) to apex of article 7 (dactylus): $143 \pm 10 \%$ [119-172\%] of CL. Length relations of above articles (in percentages of pereopod III length): $10 \pm 1 \%$ [7-12\%], $34 \pm 1 \%$ [31-36\%], $18 \pm 1 \%$ [16-20\%], $31 \pm 1 \%$ [28-34\%] and $7 \pm 1 \%$ [5-8\%]. Article 7 with $6.5 \pm 1.4$ [4-10] spiniform setae. Article 6 with $5.9 \pm 1.5$ [4-10] groups of spiniform setae.

Pleopod I (Figure 2PlpI(f)) endopodite length $17 \pm 3 \%$ [10-23\%] of CL and $38 \pm 7 \%$ [24-51\%] of exopodite length. Endopodite basis wide, remarkably tapering distally. Distal endopodite extension possibly representing appendix interna (according to its location), but without retinacular hooks.

Pleopod II (Figure 2PlpII(f)) without appendix masculina.

Distribution. The subspecies is distributed in SE Slovenia, in NW parts of its Dolenjska region, mainly covering the Suha Krajina: from Stična $27 \mathrm{~km} \mathrm{SE}$ of Ljubljana, along the upper course of the Krka River to Novo mesto and further in the SE direction to the Kolpa/Kupa River near Kostel at the border with Croatia (Figure 1). 
Remarks. According to Kollar (1848), the type sample (not explicitely designated as such) was brought to the 'k. k. Hof-Naturalien-Cabinet'. The collection is now in possession of the Naturhistorisches Museum Wien (Vienna, Austria), but the sample couldn't be found (P. Dworschak, pers. comm.). Both, Kollar and Dormitzer (1853; for its T. schmidtii) mention Kompoljska jama (Kollar also mentioned the nearby cave Potiskavc ['Portiskavcz']) as the locality of their samples. Since Kompoljska jama is easily accessible, with regularly available shrimps, it was selected as the (neo)type locality (Sket \& Zakšek 2009).

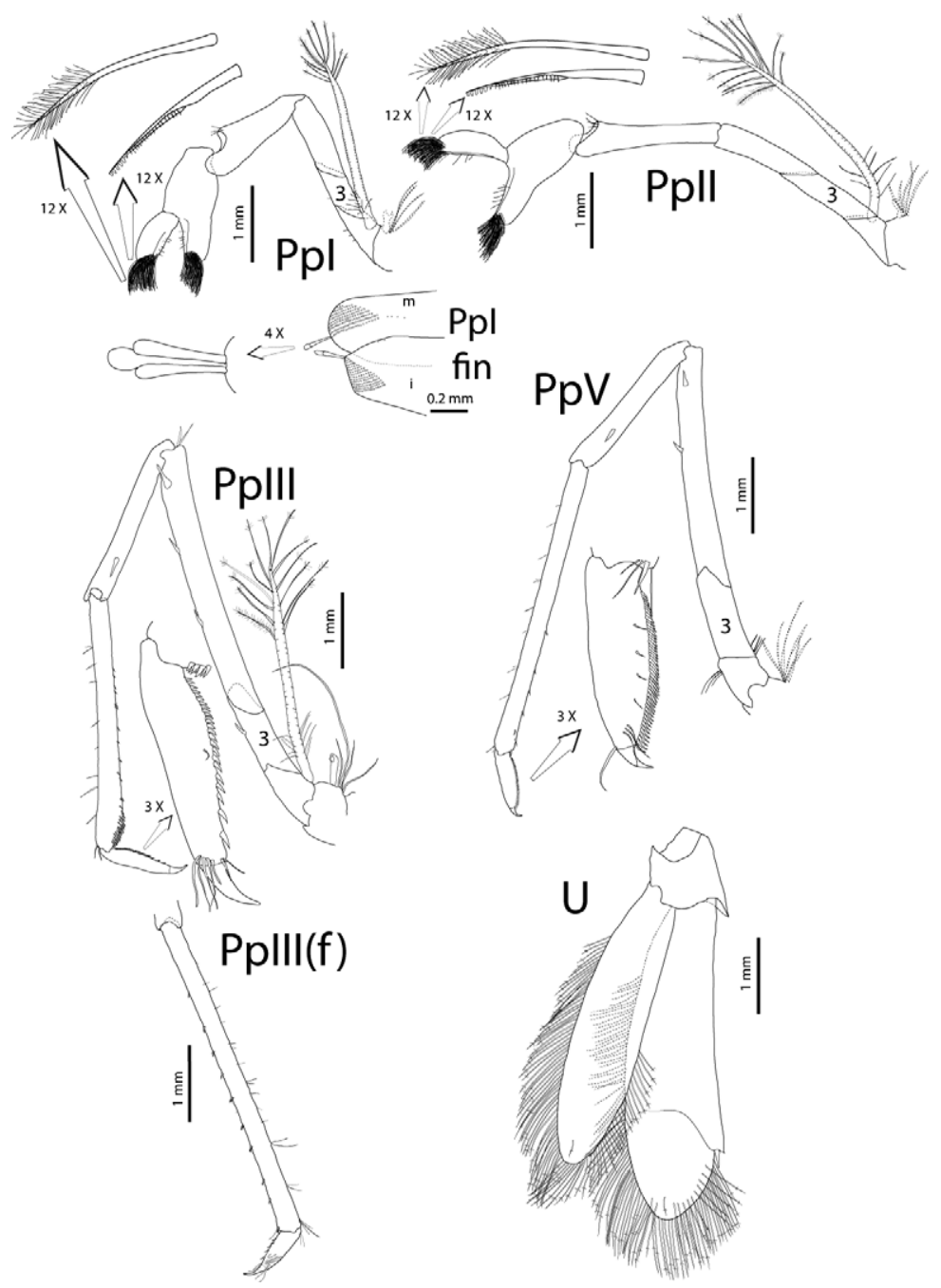

FIGURE 4. Troglocaris (Troglocaris) anophthalmus, Kompoljska jama, Kompolje, Videm-Dobrepolje, neoparatype male (TA966), CL 7.5 mm: PpI, left pereopod I; PpII, left pereopod II; PpIII, left pereopod III; PpV, left pereopod V; U, left pleopod VI (uropod). Neoallotype female (TA975), CL $8.4 \mathrm{~mm}$ : Pp III (f), distal part (articles 6 and 7) of the left pereopod III; PpIfin, placing of the setae on the movable (m) and immovable (i) fingers (equal on left and right side of the pereopods I-II). 3 pereopod article 3. Enlarged parts of the structures are indicated by arrows and their magnifications.

\section{Troglocaris (Troglocaris) anophthalmus ocellata ssp. nov.}

Synonymy: Troglocaris (Troglocaris) - the E-Slo2 subgroup Zakšek et al., 2009; Troglocaris anopthalmus intermedia Gottstein Matočec, 2003 and Franjević, 2006, p.p. (from Kukuruzovića špilja, Croatia).

Type locality: Slovenia, Vinica, cave Jama v kamnolomu.

Type sample: Males: adult male (TB046, holotype), CL $7.8 \mathrm{~mm}$, Vinica, cave Jama v kamnolomu, Slovenia, 4527'15.14" N, 15²'39.17" E, June 1977, collected by M. Štangelj, specimen partly dissected, preserved in $70 \%$ ethanol. Other males: adult male (TB045; preserved in $70 \%$ ethanol), $7.5 \mathrm{~mm}$; adult male (TB047; preserved in $70 \%$ ethanol), $8.2 \mathrm{~mm}$; same data as holotype. Females: 2 adult females, TB049 (CL $8.8 \mathrm{~mm}$ ); TB050 (CL $8.4 \mathrm{~mm}$, collected 27 May 1974) (all preserved in $70 \%$ ethanol); same data as holotype. 
Other specimens examined: over 50 specimens from 8 samples (Figure 1, Appendix C2). Males, CL 4.7-8.3 mm. Females, CL 5.0-9.0 $\mathrm{mm}$. Voucher numbers and GenBank identification numbers for COI gene are in Appendix C2.

Diagnosis: Subspecies of T. (T.) anophthalmus comprising populations with mostly pigmented eye rudiments (in more than $90 \%$ of analysed specimens; see Appendix C2 for exact localities). In mature males, appendix interna with no retinacular hooks distally, not exceeding lamina in length.

Etimology: Ocellata - adjective from Latin ocellus - with a small eye (rudiment in this case).

Remarks: In samples from Dolenjske Toplice (cave Sušica, 1 specimen) and Črnomelj (cave Stobe, 4 specimens) no specimen had pigmented eye rudiments, despite their placement in the E-Slo2 subgroup in the ITS2 and COI based phylogenetic trees (Zakšek et al., 2009). It should be noted, however, that the discriminant function analysis was run on $T$. (T.) a. ocellata together with $T$. (T.) a. anophthalmus and T. (T.) a. intermedia, as a monophylum. Therefore the appropriate differential description for T. (T.) anophthalmus ocellata is missing and only the eye specifics and data on retinacular hooks on male pleopod I are given (see also Material and methods).

Distribution: Bela Krajina (extreme SE Slovenia), contiguous to the area of T. (T.) a. anophthalmus (located north westerly). Considering only the exsistence of pigmented eye rudiment also the population of the geographicaly remote Kukuruzovića špilja near Rakovica (Croatia, at the NW Bosnian border) should be assigned to $T$. (T.) a. ocellata (Figure 1).

\section{Troglocaris (Troglocaris) anophthalmus intermedia Babić, 1922}

Synonymy: Troglocaris schmidti var. intermedia Babić, 1922; Troglocaris intermedia d'Udekem d'Acoz, 1999; nec Troglocaris anopthalmus intermedia Gottstein Matočec, 2003 and Franjević, 2006, from Kukuruzovića špilja (Croatia).

Type locality: Croatia, Ogulin, Slunj-Tounj, Mikašinovići, Mikašinovića pećina (= pećina Zala).

Specimens examined: 29 specimens from Mikašinovića pećina (Figure 1, Appendix C3). Only specimens collected from Mikašinovića pećina have been attributed to this subspecies. Voucher numbers and GenBank identification numbers for COI gene are in Appendix C3.

Preliminary (see remarks) diagnosis: Specimens from the type locality without pigmented eye rudiments and with rostrum length less than $35 \%$ of CL. In mature males, appendix interna with no retinacular hooks distally, not exceeding lamina in length.

Remarks and distribution: Presently certified only from Mikašinovića pećina, but morphologically similar populations are known from the vicinity (they were too old to be analysed molecularly): wider Ogulin area, e. g. cave Privis and cave Rudnica (see Figure 1, Appendix C3). The appropriate morphological characterisation of the subspecies will be possible when fresh samples for the molecular analysis will be obtained from the mentioned area. Since the rostral length in Troglocaris s. str. seems to be dependent on the presence of the predatory Proteus anguinus Laurenti (see Jugovic et al., 2010b), we can not admit the identification of the subspecies only on the basis of this character (rostral length was used as a key character in original description). The lack of pigment in the eye rudiments distinguishes this population from the geographically closest $T$. (T.) a. ocellata. In the COI based phylogenetic tree, the population from Mikašinovića pećina is separated from T. (T.) a. anophthalmus and T. (T.) a. ocellata, but splits are weakly supported.

\section{Troglocaris (Troglocaris) anophthalmus periadriatica ssp. nov.}

Synonymy: Troglocaris (Troglocaris) - the Adriatic phylogroup Zakšek et al., 2009 incl. Troglocaris schmidti auct. from Vjetrenica, p.p.; incl. Troglocaris schmidti schmidti forma typica Fage, 1937 p.p.; incl. Troglocaris anophthalmus Matjašič, 1960.

Type locality: Bosnia and Hercegovina, Popovo polje, Zavala, cave Vjetrenica.

Type sample: Male: adult male (TA063, holotype), CL $6.0 \mathrm{~mm}$, lake at the end of Blatni rov, Gornji Absolonov kanal, cave Vjetrenica, Popovo polje, Bosnia and Hercegovina, 42 $50^{\prime} 43.21^{\prime \prime} \mathrm{N}, 17^{\circ} 59^{\prime} 09.26^{\prime \prime} \mathrm{E}, 18^{\text {th }}$ August 2005, collected by M. Zagmajster, specimen partly dissected, preserved in $70 \%$ ethanol. Females: 7 adult females, TA794 (CL 6.9 mm); TA795 (CL $6.0 \mathrm{~mm}$ ); TA796 (CL $6.2 \mathrm{~mm}$ ), Donja Vjetrenica, 26 $6^{\text {th }}$ September 1962, collected by J. Matjašič, other data as in holotype; TA798 (CL $6.0 \mathrm{~mm}$ ); TA799 (CL $5.2 \mathrm{~mm}$ ), TA800 (CL $7.0 \mathrm{~mm}$ ), data as in holotype; TA801 (CL $6.6 \mathrm{~mm}$ ), lake Duguljasto jezero, Gornji Absolonov kanal, other data as for TA798-TA800; one juvenile female, TA797 (CL 6.0 mm), 
data as for holotype (all specimens preserved in $70 \%$ ethanol).

Other specimens examined: 29 adult males, CL 4.8-7.3 mm and 53 adult females, CL 5.2-8.7 mm, from 15 samples from the entire distribution area of $T$. (T.) a. periadriatica (Figure 1, Appendix C4). Voucher numbers and GenBank identification numbers for COI gene are in Appendix C4.

Diagnosis: Subspecies of $T$. (T.) anophthalmus with completely reduced eye and body pigmentation. Rostrum length variable, but even when rostrum longer than $45 \%$ of $\mathrm{CL}$, dorsal margin usually straight, ventral margin with 9 or less teeth, but mostly with less than 7 teeth. Antenna I article 3 length usually more than $1 / 2$ of article 2 length. Pereopod III article 4 usually with three spiniform setae along inferior margin and at inferodistal angle, article 6 weakly or strongly curved in adult males. Pereopod V article 7 length usually more than $21 \%$ (in males) and more than $17 \%$ (in females) of article 6 length. Pereopod V only exceptionally with exopodite. Uropod exopodite width usually more than $32 \%$ of its length. Telson usually strongly narrowed distally. Fully mature males with 2-7 retinacular hooks on pleopod I appendix interna, sometimes with a single retinacular hook or without them. Medial margin of pleopod I endopodite with short spiniform setae.

Differential description of material examined: Males (average values \pm SD and [min, max values] presented from Figure 5; see also Appendix B1): Small bulky specimens, CL: $6.0 \mathrm{~mm} \pm 0.6 \mathrm{~mm}$ [4.8, $7.3 \mathrm{~mm}]$. Rostrum length and dentition variable, only exceptionally rostrum curved. Article 3 of antenna I long (a13a12), its length 58 $\pm 6 \%$ [46, $73 \%$ ] of article 2 length. Antenna II scaphocerite wide (a2s2s1), its width $38 \pm 2 \%$ [33, $42 \%$ ] of scaphocerite length. Pereopod I article 7 long (pr1da), its length $21 \pm 1 \%$ [18, $23 \%$ ] of pereopod I length; and pereopod III article 7 of medium length (pr3da), its length $10 \pm 1 \%[8,12 \%]$ of pereopod III length. Pereopod I article 6 long (pr1che), its length $25 \pm 2 \%$ [22, $27 \%$ ] of CL. Uropod exopodite wide (u21, u2cl), its width $35 \pm 2$ $\%$ [32, 39\%] of uropod exopodite length, and $20 \pm 2 \%$ [17, $24 \%]$ of CL. Pereopod V article 7 long (p5dp), its length $25 \pm 2 \%$ [21, $28 \%$ ] of pereopod $V$ article 6 length. Telson short (te1s6), its length only $89 \pm 6 \%$ [76, 103 $\%$ ] of pleonite VI length. Adult males generally with at least one (up to 7) retinacular hooks on appendix interna of pleopod I endopodite. Females (average values \pm SD and [min, max values] presented from Figure 5; see also Appendix B2): Small bulky specimens, CL: $6.9 \pm 0.7 \mathrm{~mm}$ [5.2, $8.7 \mathrm{~mm}$ ]. Rostrum length and dentition variable, rostrum curved only exceptionally. Article 3 of antenna I long (a13a12), its length $55 \pm 6 \%$ [44, 69\%] of article 2 length. Antenna II scaphocerite wide (a2s2s1, a2s2cl), its width $39 \pm 3 \%$ [32, 47\%], of scaphocerite length, and 21 $\pm 2 \%[17,24 \%]$ of CL. Distal articles (article 7) of chelate pereopods I and II long (pr1da, pr2da), its length $21 \pm$ $1 \%[19,23 \%]$ of pereopod I length, and $17 \pm 1 \%[15,19 \%]$ of pereopod II length; chelae of pereopod II relatively long (pr2che), their length $23 \pm 2 \%$ [19, $28 \%]$ of CL. Proximal articles of chelate pereopods of medium length; length of article 4 of pereopod I (pr1ma) $24 \pm 2 \%$ [20, 26\%] of pereopod I length, and length of article 5 of pereopod II (pr2ccl) $27 \pm 2 \%$ [20,31\%] of CL. Pereopod V article 7 long (p5dp), its length $25 \pm 2 \%$ [17, $29 \%$ ] of article 6 length. Pleonites V-VI long (s56cl), their length $85 \pm 5 \%$ [73, $97 \%$ ] of CL. Uropod exopodite wide (u21, u2cl), its width $37 \pm 2 \%$ [32, $43 \%$ ] of uropod exopodite length, and $20 \pm 2 \%$ [16, $24 \%$ ] of CL. Uropod exopodite of medium length (u1te1), its length $108 \pm 6 \%$ [98, 121\%] of telson length; telson short (te1cl, te1s56), its length $49 \pm 3 \%[43,55 \%]$ of CL, and $59 \pm 3 \%$ [54, $63 \%]$ of pleonites V+VI length. Telson clearly narrowed distally (tes2tes1): its distal width $56 \pm 7 \%$ [43, $70 \%$ ] of proximal width. Males and females (see also Table 1): article 3 of pereopod III with 3 or less spiniform setae along its inferior margin and at inferodistal angle in over $80 \%$ of specimens, otherwise with up to 5 spiniform setae.

Etymology: Peri- in a composite word comes from a Greek word meaning "near, around". Accentuating its distribution area along and within the Adriatic coast and resembling the dessignation 'Adriatic' in the phylogenetic studies (Zakšek et al. 2007, 2009).

Remarks: Vjetrenica is chosen as the type locality, because the population of Troglocaris s. str. living in Vjetrenica has been so often mentioned in literature. It was often regarded as belonging to the 'typical' $T$. anophthalmus (e.g. Matjašič, 1960) or even explicitly as being T. a. anophthalmus (Fage 1937, as T. s. schmidti; Franjević 2006).

Distribution: The subspecies inhabits a contiguous wide area along the Adriatic coast, approximately from Otočac in Lika (Croatia) in NW to SE of Trebinje (Bosnia and Hercegovina) in SE. It seems to be absent from the central Velebit mountains (Croatia), but it is present in the detached peninsula Pelješac and the islands of Brač and Ugljan. The populations W and NW of Otočac were not available for study (Figure 1). 


\section{Troglocaris (Troglocaris) anophthalmus sontica ssp. nov.}

Synonymy: Troglocaris (Troglocaris) - the Soča phylogroup Zakšek et al., 2009

Type locality: Slovenia, Vipava, cave Vipavska jama.

Type sample: Males: adult male (TA985, holotype), CL $7.4 \mathrm{~mm}$, Vipavska jama, Vipava, Slovenia, 4550'40.91" N, $13^{\circ} 57^{\prime} 52.55^{\prime \prime}$ E, $6^{\text {th }}$ September 2009, collected by J. Jugovic and M. Kolesnikova, specimen preserved in $70 \%$ ethanol. Other males from the type sample: adult male (TA983), CL $6.1 \mathrm{~mm}$; adult male (TA984), CL $6.3 \mathrm{~mm}$; adult male (TA986), CL $6.6 \mathrm{~mm}$; adult male (TA987), CL $6.2 \mathrm{~mm}$; adult male (TA988), CL $5.6 \mathrm{~mm}$; same data as neotype. Females: 5 adult females, TA990 (CL $7.1 \mathrm{~mm}$ ); TA991 (CL $6.1 \mathrm{~mm}$ ); TA992 (CL $6.4 \mathrm{~mm}$ ); TA993 (CL $6.1 \mathrm{~mm})$; TA994 (CL $6.2 \mathrm{~mm}$ ); same data as neotype.

Other specimens examined: 9 specimens collected from one other known locality of T. (T.) anophthalmus sontica (Figure 1, Appendix C5). Males, CL 5.0-6.8 mm. Females, CL 5.9-7.0 mm. Molecular analysis only: 6 specimens from two additional localities (Figure 1, Appendix C5). Voucher numbers and GenBank identification numbers for COI gene are in Appendix C5.

Diagnosis: Subspecies of T. (T.) anophthalmus with completely reduced eye and body pigmentation. Rostrum length variable, rostrum always straight and narrow, with 7 or less ventral teeth. Antenna I article 3 length less than 1/2 of article 2 length. Antenna II scaphocerite's distal point weak, usually its length less than $28 \%$ of scaphocerite width. Pereopod III article 4 usually with four spiniform setae along inferior margin and at inferodistal angle, article 6 not or only weakly curved in adult males. Pereopod V exopodite absent. Uropod exopodite width usually less than $32 \%$ of its length. Fully mature males without retinacular hooks on pleopod I endopodite appendix interna. Pleopod I endopodite inner margin with short spiniform setae. Medial margin of pleopod I endopodite with short spiniform setae.

Differential description of material examined: Males (average values \pm SD and [min, max values] presented, Figure 5; see also Appendix B1): Small specimens, CL: $5.8 \pm 0.5 \mathrm{~mm}$ [5.0, $6.8 \mathrm{~mm}$ ]. Rostrum length and dentition variable, when rostrum longer than $45 \%$ of CL, narrow and never curved upwards. Article 3 of antenna I short (a13a12), its length $39 \pm 4 \%$ [33, $46 \%$ ] of article 2 length. Antenna II scaphocerite narrow (a2s 2 s1), its width $34 \pm$ $2 \%[31,38 \%]$ of scaphocerite length; distal point of scaphocerite weak and short (a2s3s1), its length $7 \pm 1 \%$ [5, $10 \%$ ] of scaphocerite length. Pereopod I article 7 long (pr1da), its length $21 \pm 2 \%$ [19, $24 \%$ ] of pereopod I length; and pereopod III article 7 short (pr3da), its length only $9 \pm 1 \%$ [7, 12\%] of pereopod III length. Pereopod I article 6 long (pr1che), its length $26 \pm 2 \%$ [22, $29 \%$ ] of CL. Pereopod III article 3 long (pr3ia), its length $9 \pm 1 \%$ [8, 11 $\%$ ] of pereopod III length. The comb on pereopod V article 7 with small number of setae $(P 5 D): 36.8 \pm 4.3$ [32, 47]. Pereopod V article 7 short (p5dp), its length only $21 \pm 2 \%$ [17, 24\%] of pereopod V article 6 length. Uropod exopodite narrow ( $\mathrm{u} 21, \mathrm{u} 2 \mathrm{cl}$ ), its width only $29 \pm 2 \%$ [27, $32 \%$ ] of uropod exopodite length, and $16 \pm 1 \%$ [14, 18 $\%$ ] of CL. Telson long (te1s6), its length $97 \pm 5 \%$ [89, $103 \%$ ] of pleonite VI length. Adult males generally without a single retinacular hook on appendix interna of pleopod I endopodite. Number of setae on pleopod I endopodite inner margin small (PPIENS): $18.9 \pm 2.8$ [15, 24]. Females (average values \pm SD and [min, max values], Figure 5; see also Appendix B2): Small specimens, CL: $6.5 \pm 0.4 \mathrm{~mm}$ [5.9, $7.0 \mathrm{~mm}]$. Rostrum length and dentition variable, when longer than $45 \%$ of CL, narrow and never curved upwards. Article 3 of antenna I short (a13a12), its length only $38 \pm 7 \%$ [31, $50 \%$ ] of article 2 length. Antenna II scaphocerite narrow (a2s $2 \mathrm{~s} 1$, a2s $2 \mathrm{cl}$ ), its width $36 \pm 2 \%$ [30, $38 \%]$ of scaphocerite length, and $17 \pm 1 \%$ [16, $19 \%]$ of CL; distal point of scaphocerite weak and short (a2s3s1), its length only $8 \pm 1 \%$ [6, $9 \%$ ] of scaphocerite length. Distal articles of chelate pereopods long; length of article 7 of pereopod I (pr1da) $21 \pm 1 \%$ [20, $22 \%$ ] of pereopod I length, and length of article 7 of pereopod II (pr2da) $18 \pm 1 \%$ [17, $19 \%$ ] of pereopod II length. Pereopod II chelae long (pr2che), their length $24 \pm 1 \%$ [23, 26 $\%$ ] of CL. Proximal articles of chelate pereopods long, length of pereopod I article 4 (pr1ma) $23 \pm 1 \%$ [22, $25 \%$ ] of pereopod I length, and length of pereopod II article 5 (pr2ccl) $26 \pm 2 \%$ [23, $28 \%$ of CL. Pereopod V article 7 short (p5dp), its length only $19 \pm 2 \%[16,22 \%]$ of pereopod V article 6 . The comb on pereopod V article 7 with small number of setae $(P 5 D): 35.9 \pm 3.0$ [31, 40]. Pleonites V-VI long in relation to CL (s56cl), its length $78 \pm 3 \%$ [71, $80 \%$ ], and short in relation to uropod exopodite length (u1s56), its length $64 \pm 3 \%$ [61, 71\%] of uropod exopodite length. Uropod exopodite narrow ( $\mathrm{u} 21, \mathrm{u} 2 \mathrm{cl})$, its width only $31 \pm 1 \%$ [29, $33 \%$ of uropod exopodite length, and only $16 \pm 1 \%$ [14, $16 \%$ ] of CL. Pleopod II appendix interna short (pl2aicl), its length $10 \pm 1 \%$ [9, 12 $\%$ ] of CL. Telson of medium length (te1cl, te1s56), its length $50 \pm 3 \%$ [47, 55\%] of CL, and $64 \pm 3 \%$ [62, $71 \%$ ] of pleonites V+VI length. Telson weakly narrowed distally (tes2tes1), its distal width $79 \pm 7 \%$ [69, 89\%] of proximal width. Males and females (see also Table 1): pereopod III article 3 with 4-5 spiniform setae along its inferior margin and at inferodistal angle in over $70 \%$ of specimens, otherwise with 3 spiniform setae.

Etymology: Sontica is an adjective from Sontius (or Aesontius) which was the Roman name for the river Soča/Isonzo. 
Distribution: despite the thorough examination of the area (Jugovic and Zakšek, 2008; Prevorčnik, Fišer, Zagmajster, Trontelj, 2009) the subspecies is known only from four localities (Figure 1, Appendix C5) in the Soča-Vipava rivers system, NW from T. (T.) planinensis. Both taxa seem to be sympatric in the Italian Carso/Kras.

\section{Troglocaris (Troglocaris) anophthalmus legovici ssp. nov.}

Synonymy: Troglocaris (Troglocaris) - the Istra putative phylogroup Zakšek et al., 2009

Type locality: Croatia, Pula, Nimfej izvor (spring).

Type material: Male: adult male (inv. number 1770, holotype), CL $5.7 \mathrm{~mm}$, Nimfej izvor, Pula, Croatia, 25 ${ }^{\text {th }}$ January 2011 , collected by B. Jalžić, specimen partly dissected and stored in $96 \%$ ethanol. Females from the type locality: 2 juvenile females: TB082 (CL $5.6 \mathrm{~mm}$ ), TB084 (CL $5.7 \mathrm{~mm}$ ). Type material stored in Hrvatski prirodoslovni muzej in Zagreb (Croatia).

Other specimens examined: Kršan (female, CL $6.2 \mathrm{~mm}$ ). Molecular analysis only: Opatija, Medveja (juvenile male); Vrsar, Klariča jama (female, only tissue available). Voucher numbers and GenBank identification numbers for COI and ITS2 genes are in Appendix C6, where available.

Description of the holotype (only characters that are used for differential descriptions of other herein described taxa are included, see also Table 1 and Appendix B1): Small specimen, CL: $5.7 \mathrm{~mm}$. Rostrum straight and narrow, with 4 ventral teeth. Article 3 of antenna I length (a13a12) $50 \%$ of article 2 length. Antenna II scaphocerite narrow (a2s $2 \mathrm{~s} 1)$, its width $34 \%$ of scaphocerite length; distal point of scaphocerite $9.5 \%$ of scaphocerite length $(\mathrm{a} 2 \mathrm{~s} 3 \mathrm{~s} 1)$. Pereopod I article 7 length (pr1da) $17 \%$ of pereopod I length; pereopod III article 7 length (pr3da) $11.5 \%$ of pereopod III length. Pereopod I article 6 length (pr1che) $22 \%$ of CL. Pereopod III article 3 long (pr3ia), its length $10.5 \%$ of pereopod III length. The comb on pereopod V article 7 with small number of setae (P5D), only 30. Pereopod V article 7 rather short (p5dp), its length $18 \%$ of pereopod V article 6 length. Uropod exopodite narrow (u21, u2cl), its width $29 \%$ of uropod exopodite length and $18.5 \%$ of CL. Telson long (te1 s6), its length $97 \%$ of pleonite VI length. Pleopod I endopodite without retinacular hooks on appendix interna. Number of setae on pleopod I endopodite inner margin (PPIENS) small, only 21. Article 3 of pereopod III with 4 spiniform setae along its inferior margin and at inferodistal angle. Females: no adult females from the type locality were available, but see Appendix B2 for scarce morphometric data.

Etymology: named after the well known Istrian caver and our friend Silvije Legović.

Remarks and distribution: Only populations from W and E coast of the central Istra peninsula (Croatia), S from rivers Mirna and Raša, together with a sample from the southern tip of peninsula (near Pula) could be molecularly identified as belonging to the Istra putative phylogroup (Figure 1). In Kršan (in a spring in the tunnel draining the former lake of Čepić), it was found in syntopy with $T$. (T.) planinensis, where the latter was more numerous. Near Pula, $T$. (T.) planinensis was also found (but not in the same locality). So these populations might represent separate biological species either on their own or as a member of herein described T. (T.) anophthalmus.

\section{Troglocaris (Troglocaris) planinensis Birštejn, 1948}

Synonymy: Troglocaris schmidti planinensis Birštejn, 1948; Troglocaris planinensis d'Udekem d'Acoz, 1999; T. anophthalmus - the W-Slovenian phylogroup Zakšek et al., 2007; incl. Troglocaris anophthalmus anophthalmus, Gottstein Matočec, 2003, p.p. (from Jama pod Krogom); incl. Troglocaris 'forma A2' (Plomin) Franjević, 2006; incl. Troglocaris 'forma AN' (Krog) Franjević, 2006; incl. Troglocaris hercegovinensis Sket, 1992 from Slovenia (Osp); see also Holthuis (1956).

Type locality: Slovenia, Postojna, Planina, cave Planinska jama.

Type material: Birštejn's sample is supposed to be in his collection in the Zoologičeskij institut, Moskovskyj Gosudarstvennyj Universitet in Moskva (Moscow, Russia). The author of the subspecies did not declare the holotype. Since his only male is evidently juvenile, choosing a lectotype would be of little practical value. Therefore we decided to choose a neotype from a new sample from the topotype population.

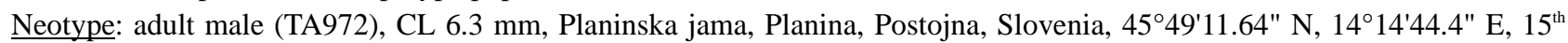
October 2009, collected by J. Jugovic and M. Vittori, specimen partly dissected and stored in $70 \%$ ethanol. Other specimens from the neotype locality: Males: adult male (TA973), $6.6 \mathrm{~mm}$; adult male (TA974), CL $7.0 \mathrm{~mm}$; same data as neotype. Females: 3 adult females, TA969 (CL 7.7 mm); TA970 (CL $7.4 \mathrm{~mm}$ ); TA971 (CL $7.4 \mathrm{~mm}$ ); same data as neotype.

Other specimens examined: over 200 specimens from 32 samples (Figure 1, Appendix C7). Males, CL 5.1-8.2 mm. Females, CL 4.0-9.9 mm. Voucher numbers and GenBank identification numbers for COI gene are in Appendix C7. 


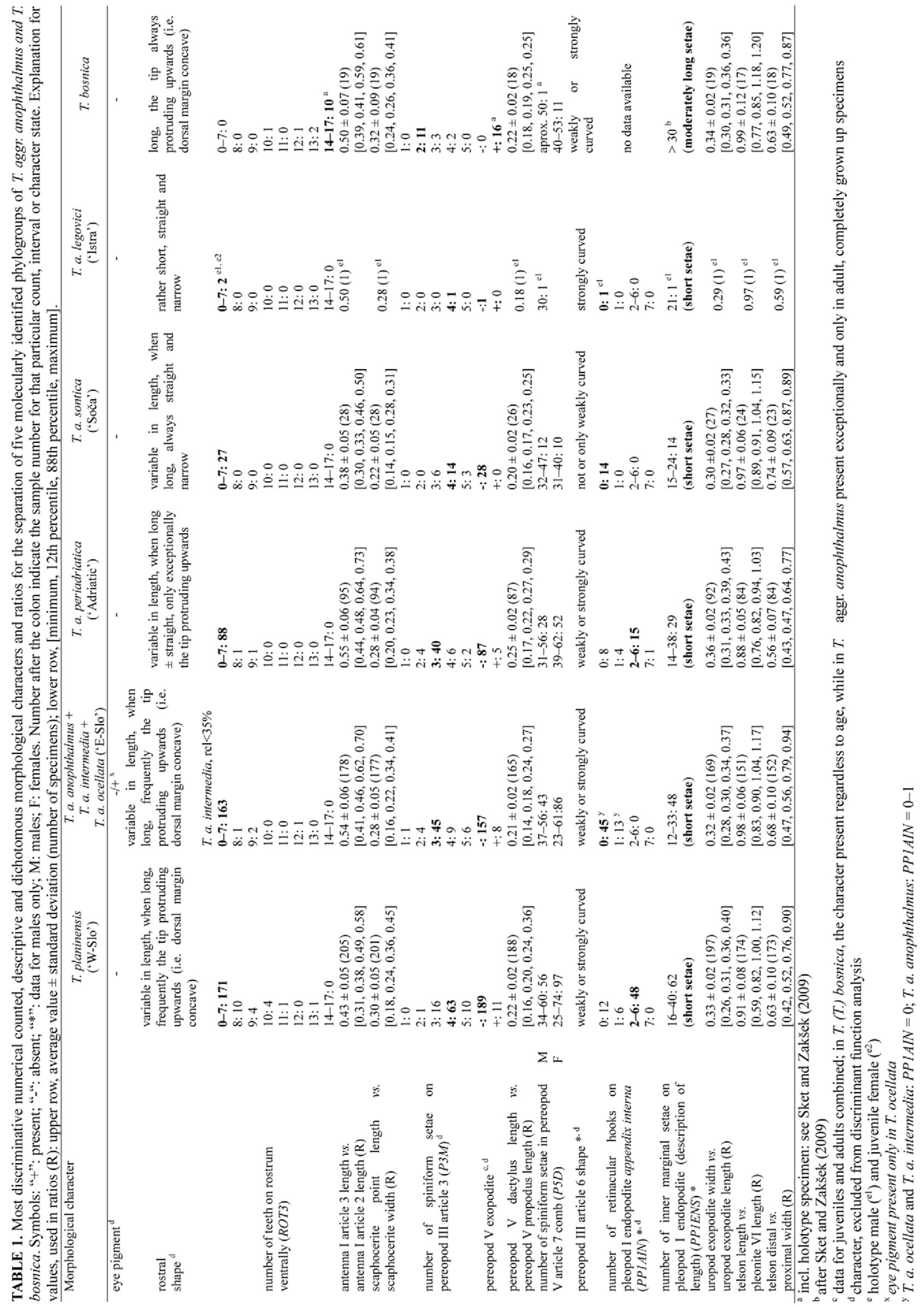


Diagnosis: Species of Troglocaris sg. Troglocaris with completely reduced eye and body pigmentation. Rostrum length and dentition variable, when rostrum longer than $45 \%$ of CL, dorsal margin usually curved upwards, ventral margin with less than 13, mostly with less than 7 teeth. Antenna I article 3 length usually less than $1 / 2$ of article 2 length. Pereopod III article 4 usually with 4-5 spiniform setae along inferior margin and at inferodistal angle, article 6 weakly or strongly curved in adult males. Pereopod V only exceptionally with exopodite. Fully mature males with 1-6 retinacular hooks on appendix interna of pleopod I endopodite, only exceptionally without them. Medial margin of pleopod I endopodite with short spiniform setae.

Differential description of material examined: Males (average values $\pm \mathrm{SD}$ and [min, max values] presented, Figure 5; see also Appendix B1): Large specimens, CL: $6.6 \pm 0.8 \mathrm{~mm}$ [5.1, 8.2 mm]. Rostrum length and dentition variable, when rostrum longer than $45 \%$ of CL, usually curved upwards. Article 3 of antenna I of medium length (a13a12), its length $44 \pm 5 \%[33,57 \%]$ of article 2 length. Antenna II scaphocerite of medium width (a2s2s1), its width $35 \pm 3 \%$ [28, $41 \%$ ] of scaphocerite length. Pereopod I article 7 short (pr1da), its length only $20 \pm 2 \%$ [16-24\%] of pereopod I length. Pereopod III article 7 of medium length (pr3da), its length $11 \pm 2 \%[6,14 \%]$ of pereopod III length. Pereopod I article 6 length short (pr1che), its length only $23 \pm 2 \%$ [19, $28 \%$ ] of CL. Uropod exopodite of medium width (u21, u2cl), its width $32 \pm 2 \%$ [28, 36 \%] of uropod exopodite length, and $18 \pm 2 \%$ [15, 23\%] of CL. Pereopod V article 7 of medium length (p5dp), its length $22 \pm$ $2 \%[18,26 \%]$ of pereopod $\mathrm{V}$ article 6 length. Telson short (te1s6), its length only $91 \pm 7 \%$ [75, $106 \%]$ of pleonite VI length. Adult males generally with at least one (up to 6) retinacular hook on appendix interna of pleopod I endopodite. Females (average values \pm SD and [min, max values] presented, Figure 5; see also Appendix B2): Large specimens, CL: $7.8 \pm 0.9 \mathrm{~mm}[5.5,9.9 \mathrm{~mm}]$. Rostrum length and dentition variable, when rostrum longer than $45 \%$ of CL, dorsal margin usually curved upwards. Article 3 of antenna I short to medium long (a13a12), its length $43 \pm 5 \%$ [31, $58 \%]$ of article 2 length. Antenna II scaphocerite of medium width (a2s2s1, a2s2cl), its width $37 \pm 3 \%$ [30, $42 \%$ ] of scaphocerite length, and $19 \pm 2 \%$ [14, 24\%] of CL. Distal articles of chelate pereopods of medium length: length of article 7 of pereopod I (pr1da) $19 \pm 2 \%$ [14, $25 \%$ ] of pereopod I length, and length of article 7 of pereopod II (pr2da) $15 \pm 2 \%$ [12, 19\%] of pereopod II length. Chelae (article 6) of pereopod II short (pr2che), their length only $22 \pm 2 \%$ [17, 28 \%] of CL. Proximal articles of chelate pereopods rather long: article 4 of pereopod I length (pr1ma) $25 \pm 2 \%$ [21, 29\%] of pereopod I length, article 5 of pereopod II length (pr2ccl) $28 \pm 4 \%$ [21, $38 \%$ ] of CL. Pereopod V article 7 of medium length (p5dp), its length $22 \pm 2 \%$ [16, $29 \%$ ] of pereopod V article 6 length. Pleonites V-VI short (s56cl), their length only $79 \pm 5 \%$ [67, 95\%] of CL. Uropod exopodite long (u1te1), its length $110 \pm 7 \%$ [97, $130 \%$ ] of telson length. Telson short to medium long (te1cl, te1s56), its length $48 \pm 3 \%$ [40, $57 \%$ ] of CL, and $62 \pm 4 \%$ [51, 72 $\%$ ] of pleonites V+VI length. Telson distally narrowed (tes2tes 1 ), its distal width $65 \pm 9 \%$ [47, $90 \%$ ] of proximal width. Males and females (see also Table 1): Article 3 of pereopod III with $4-5$ spiniform setae along its inferior margin and at inferodistal in over $80 \%$ specimens, otherwise 2-3.

Distribution: This species inhabits the Planina-Postojna Cave System, its close surroundings, the areas W and SW from the type locality (SW Slovenia), Kras/Carso (SW Slovenia and extreme NE Italy) and the northern part of the Istra peninsula in Slovenia and Croatia. It was also molecularly identified from the southern tip of the Istra peninsula (near Pula/Pola; Zakšek and Moškrič, unpublished) (Figure 1).

\section{Troglocaris (Troglocaris) bosnica Sket et Zakšek, 2009}

Synonymy: Troglocaris sp. nov. 2 of the Bosnian clade, Zakšek et al., 2007

Specimens examined: Suvaja pećina cave, Sanski Most, Bosnia and Hercegovina: 1 juvenile male, CL 6.2 mm; 13 mature females, CL 5.8-7.4 mm; 4 juvenile females, CL 5.0-5.5 mm. Dabarska pećina cave, Sanski Most, Bosnia and Hercegovina: 1 adult female, CL $8.8 \mathrm{~mm}$ (voucher numbers are in Appendix C8; for GenBank identification numbers for COI gene see Sket \& Zakšek 2009).

Emended diagnosis: Species of Troglocaris sg. Troglocaris with completely reduced eye and body pigmentation. As for the subgenus, rostrum length $55 \%$ of CL or longer, usually with 13 or more ventral teeth (exceptionally 12-10 teeth); palp of maxilla I with more than three, moderately long setae; male pleopod I endopodite with more than 30 partially grouped, and long, inner marginal setae. Pereopod V exopodite well developed. 
Remarks:Males: the holotype was the only adult male available. Except for the age dependent characters (pereopod III-IV article 6 differentiation), no other differences from the species diagnosis (Sket \& Zakšek 2009) are present in the only juvenile male. Females: no differences from the species diagnosis (Sket \& Zakšek 2009) present.

It should be stressed that not only all adult males and females (in contrast to the vast majority of $T$. aggr. anophthalmus specimens), but also all juveniles have well developed exopodites on pereopod $\mathrm{V}$.

Distribution: The subspecies is known only from two caves in Bosanska Krajina (westernmost Bosnia and Hercegovina, Figure 1). The populations from the Bihać region between Lušci polje (Bosnia and Hercegovina) and Kukuruzovića pećina (Croatia) were available neither for molecular nor for the morphometric study; they could belong to this or to any of the neighbouring taxa.

\section{Discussion}

A recognition and formalization of cryptic species is nowadays declared to be a major challenge to modern taxonomy (Heinrichs et al. 2011, Hekkala et al. 2011). This is also reflected in an exponential growth of publications on cryptic species observed during the past two decades (Pfenninger \& Schwenk 2007). The term was circumscribed as "populations which are phylogenetically distinct, but which are distinguished by molecular or other features that are either not evident macroscopically or generally overlooked" (Hawksworth 2010). Cryptic species occur when daughter taxa accumulate genetic differences without apparent morphological divergence (Bickford et al. 2006, Mathews et al. 2002), the term "apparent" usually referring to the use of the traditional taxonomic techniques (Schutze et al. 2012) in search for morphological distinction.

After the reconstruction of its phylogeny, an overall morphological investigation of the subgenus Troglocaris $\mathrm{s}$. str. was necessary to improve the existent knowledge on its intra- and interspecies morphological diversification. Yet, providing the basis for the morphological distinction of the taxa described herein in order to achieve their taxonomical visibility has proven to be anything but simple. Although a huge set of morphometric data was gathered and processed, the results of a non-biased multivariate primary component analysis (Jugovic, unpubl.) did not correspond to the molecular results. Only after using the established phylogenetic framework for delimiting taxa a subsequent Discriminant Function Analysis (DFA) revealed minimal morphological differences (Figure 5). These differences, however, are manifested as complex combinations of morphological characters, demanding the employment of the PC supported Multivariate statistical tools. Aditionally, gender and age of specimens turned out to have a significant impact on the identification capability. Due to the negligible convenience and applicability of the given descriptions, we believe that one can still reasonably consider the herein described taxa of Troglocaris $\mathrm{s}$. str. as cryptic, despite the provided morphological descriptions/diagnoses and quite loose (arbitrary) definitions of cryptic taxa (i.e. with features that are not evident macroscopically; taxa are very morphologically similar).

Some characters (listed and explained further in the text) were excluded from the DFA owing to deviations from the required DFA's assumptions (i.e. normal distribution, low correlation coefficients, a few missing data). Nevertheless, they somewhat support the separation of herein described taxa and with their simultaneous consideration, the reliability of taxonomic separation increases. The most discriminative of the characters excluded from the multivariate statistical analysis (Table 1, characters marked as “d”), is the presence of pigment in the eyes. It has been found only in $T$. (T.) a. ocellata ssp. nov., in the majority of specimens. This is the only case of a common pigmented eye rudiment presence in the Dinaric Troglocaris (Sket 1985). Müller (1931) mentioned individual specimens with pigmented eye rudiments ('singoli individui con traccie di pigmento oculare') in the otherwise blind population from San Giovani/Štivan in the Italian Carso/Kras, i.e. within the T. (T.) planinensis distribution area. In our large samples from the same and from the nearby localities, we did not find a single specimen with the eye pigmentation. Such specimens were present exclusively within the distribution area of $T$. (T.) a. ocellata ssp. nov. Another informative morphological character is the number of retinacular hooks on the appendix interna of the adult male pleopod I (PPIAIN, see Table 1), which has not been used in the taxonomy of Troglocaris s. str. before. However, it is an age- and gender-dependent character, i.e. the hooks are absent in immature males and females. Only the adult males can therefore be used for the identification purposes (Thorpe 1983, see also Jugovic et al. 2010a). The most discriminative meristic character in both genders turned out to be the 

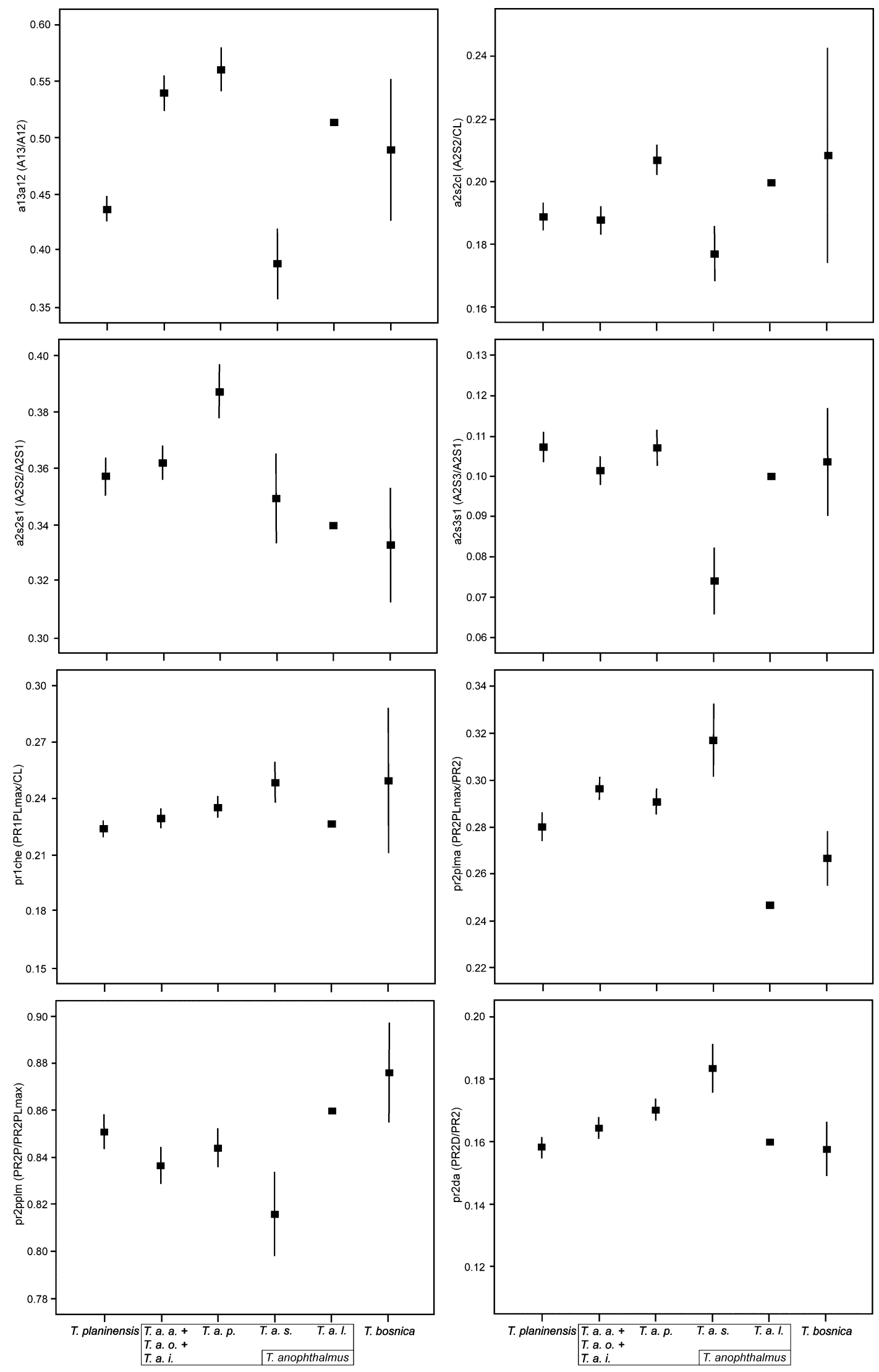

FIGURE 5a. The arithmetic mean and $99 \%$ confidence interval (where $\mathrm{N}>10$ ) of the most discriminating morphological characters (MC) for six phylogroups of Troglocaris s. str. For explanation of MCs' symbols, see taxonomic descriptions in the text. Note that T. (T.) a. - E-Slo contains T. (T.) a. anophthalmus (T. a. a.), T. (T.) a. intermedia (T. a. i.) and T. (T.) a. ocellata (T. a. o.); T. a. p. - T. (T.) a. periadriatica; T. a. s. - T. (T.) a. sontica, T. a. l. - T. (T.) a. legovici. 

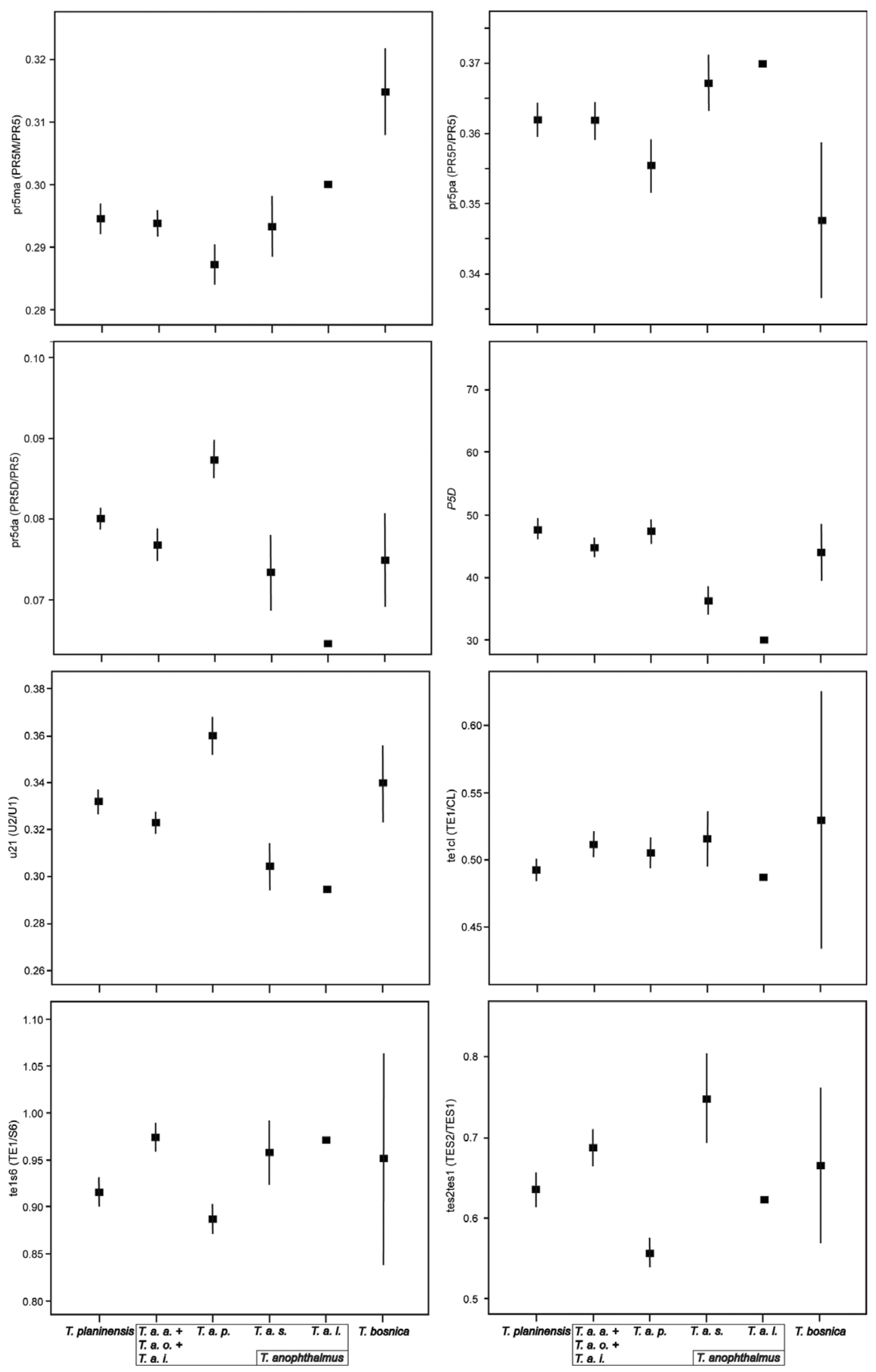

FIGURE 5b. The arithmetic mean and $99 \%$ confidence interval (where $\mathrm{N}>10$ ) of the most discriminating morphological characters (MC) for six phylogroups of Troglocaris s. str. For explanation of MCs' symbols, see taxonomic descriptions in the text. Note that T. (T.) a. - E-Slo contains T. (T.) a. anophthalmus (T. a. a.), T. (T.) a. intermedia (T. a. i.) and T. (T.) a. ocellata (T. a. o.); T. a. p. - T. (T.) a. periadriatica; T. a. s. - T. (T.) a. sontica, T. a. l. - T. (T.) a. legovici. 
number of spiniform setae on the article 4 (merus) of pereopod III (P3M, see Table 1). The character has already been used in a morphological study of three populations of $T$. aggr. anophthalmus from Slovenia (comprising also samples of $T$. (T.) planinensis and T. (T.) a. anophthalmus type populations; see Fabjan 2001), but its importance wasn't stressed. As this character is age-dependent, it can only be of use in identidication of fully mature males and females. Previously, the described species of the genus Troglocaris s. 1. (i.e. of three Dinaric subgenera, Spelaeocaris, Troglocaridella, and (in part) also Troglocaris s. str.) were mainly diagnosed by characters acquired from sexually dimorphic structures (Sket \& Zakšek 2009). The use of such characters is frequent since sexual differentiation usually represents one of the most rapid and obvious taxon-specific events during speciation in many animal groups (invertebrates in particular, e.g. see Mayr \& Ashlock 1991).

There are cases in which a detailed morphological analysis revealed distinct and easily diagnosable characters in separate phylogenetic lineages within cryptic species (e.g. Sket \& Zakšek 2009, Trape et al. 2009, De Oliveira $e t$ al. 2012). Despite our seemingly unsuccessful quest to provide such easly observable diagnostic traits, we do not consider our efforts as unreasonable. Moreover, a confirmation of the negligible morphological differences will serve as a unique starting point for further investigations. Namely, lineages exhibiting so little morphological change over time can most efficiently highlight whether non-adaptive or adaptive processes explain the conservation of morphology over evolutionary time scales (Smith et al. 2011, Schluter 2000, Milinkovitch 1995).

Due to all limitations of morphological identification stated above, we highly recommend the investigation of large samples, presumably providing a suitable number of adult males and females. The geographic origin of the investigated samples should be prevalent in identification (see data on distribution of taxa), except for the westernmost parts of the Troglocaris s. str. area (Istra and Kras/Carso, see Cobolli Sbordoni et al. 1990). There, some species do or might occur in syntopy. Molecular analysis alone (probably also the simplified DNA barcoding), however, can ensure an unambiguous identification of the taxa within Troglocaris s. str.

\section{Acknowledgements}

While most samples were collected by one of the authors of the present research (BS) and by F. Velkovrh (both Slovenia) we are further grateful to numerous friends and colleagues, who also helped collecting the material: G. Aljančič, C. Fišer, A. Hudoklin, G. Jaklič, F. Kljun, M. Pezdirc, M. Podgorelec, S. Polak, P. Presetnik, B. Ravnjak, M. Simonič, B. Šarac, M. Štangelj, P. Trontelj, M. Turjak, F. Velkovrh, R. Verovnik, M. Vittori, M. Zagmajster, V. Zakšek (all Slovenia), B. Jalžić and Hrvatski prirodoslovni muzej, R. Lattinger, S. Legović, T. Rađa (all Croatia), I. Lučić and the Speleološka udruga Vjetrenica - Popovo polje (Bosnia and Hercegovina), and M. Kolesnikova (Ukraine). We thank P. Dworschak, the curator of the Crustacean collection in the Naturhistorisches Museum Wien (Austria) for useful information about $T$. anophthalmus holotype. The work was financially supported by the Slovenian Research Agency.

\section{References}

Avise, J.C. 2000. Phylogeography: The History and Formation of Species. Harvard University Press, Cambridge, MA. 447 pp. Babić, K. (1922) Über die drei Atyiden aus Jugoslavien. Glasnik hrvatskog prirodoslovnog društva, 10, 4-10.

Birštejn, J.A. (1948) Nahoždenie peščernoj krevetki v gruntovyh vodah Macesty i svjazannye s etim voprosy. Moskovskoe obshchestvo ispytatelei prirody, 53 (3), 3-10.

Cobolli Sbordoni, M., Mattocia, M., La Rosa, G., De Matthaeis, E., Sbordoni, V. (1990) Secondary sympatric occurrence of sibling species of subterranean shrimps in the Karst. International Journal of Speleology, 19 (1/4), 9-27.

Dormitzer, M. (1853) Troglocaris Schmidtii. Lotos, 3, 85-88.

Fabjan, E. (2001) Prispevek k taksonomiji jamskih kozic Troglocaris (Crustacea: Decapoda: Atyidae). Graduation Thesis, Univerza v Ljubljani, Biotehniška fakulteta, 84 p.

Fage, L. (1937) Troglocaris schmidtii subspecies nova: inermis Crustacé décapode aveugle des eaux souterraines francaises. Archives de zoologie experimentale et generale, 78, 215-230.

Franjević, D. (2006) Molekularna filogenija dinaridskih vrsta roda Troglocaris (Crustacea, Caridea, Atyidae). Sveučilište v Zagrebu, Prirodoslovno-matematički fakultet, Biološki odsjek, doktorska disertacija (Doctoral dissertation), Zagreb, 187 pp.

Gottstein Matočec, S. (2003) Intraspecijska i interspecijska varijabilnost podzemnih kozica roda Troglocaris (Crustacea, Natantia, Atyidae) u Dinarskom kršu. Sveučilište v Zagrebu, Prirodoslovno-matematički fakultet, Biološki odsjek, doktorska disertacija (Doctoral dissertation), Zagreb, $136 \mathrm{p}$.

Hawksworth, D.L. (2010) Cryptic speciation: how common is it and how should it be handled taxonomically? <imc9.info/ prog_sig3detail_hawksworth.htm> (date of acception: $20^{\text {th }}$ January 2012) 
Heinrichs, J., Kreier, H.P., Feldberg, K., Schmidt, A.R., Zhu R.L., Shaw, B., Shaw, A.J., Wissemann, V. (2011) Formalizing morphologically cryptic biological entities: New insights from DNA taxonomy, hybridization, and biogeography in the leafy liverwort Porella platyphylla (Jungermanniopsida, Porellales) American Journal of Botany, 98, 1252-1262.

Hekkala, E., Shirley, M.H., Amato, G., Austin, J.D., Charter, S., Thorbjarnarson, J., Vliet, K.A., Houck, M.L., Desalle, R., Blum, M.J. (2011) An ancient icon reveals new mysteries: mummy DNA resurrects a cryptic species within the Nile crocodile. Molecular Ecology, doi: 10.1111/j.1365-294X.2011.05245.x

Holthuis, L.B. (1956) An enumeration of the Crustacea Decapoda Natantia inhabiting subterranean waters. Vie et Milieu, 6, $43-76$.

Juberthie-Jupeau, L. (1974) Les caractères liés a l'incubation chez Troglocaris anophthalmus et T. inermis crustacés decapodés hypogés. Annales de spéléologie, 29 (3), 389-401.

Juberthie-Jupeau, L. (1975) La ponte d'un crustacé decapodé souterrain: cycle saisonnier et influence biologique. Annales de spéléologie, 30 (1), 167-171.

Jugovic, J., Prevorčnik, S., Sket, B. (2010a) Development of sexual characters in the cave shrimps Troglocaris (Crustacea: Decapoda: Atyidae) and their applicability in taxonomy. Zootaxa, 2488, 1-21.

Jugovic, J., Prevorčnik, S., Aljančič, G., Sket, B. (2010b) The atyid shrimp (Crustacea, Decapoda, Atyidae) rostrum: Phylogeny versus adaptation, taxonomy versus trophic ecology. Journal of Natural History, 44 (41-42), 2509-2533.

Jugovic, J., Prevorčnik, S., Blejec, A., Sket, B. (2011) Morphological differentiation in the cave shrimps Troglocaris (Crustacea: Decapoda: Atyidae) of the Dinaric karst - a consequence of geographical isolation or adaptation? Journal of Zoological Systematics and Evolutionary Research, 49, 185-195.

Kollar, V. (1848) Über ein neues sehr merkwürdiges Crustaceum aus den unterirdischen Gewässern von Krain, welches Herr Custos H. Freyer an das k.k. Hof-naturalien-Cabinet eingesendet hat. Sitzungsberichte der Kaiserlichen Akademie der Wissenschenschaften Wien, 2, 200-202.

Mayr, E. (1970) Populations, species and evolution. An abridgement of animal species and evolution. Cambridge, Massachusetts and London, The Belknap Press of Harvard University press, $4^{\text {th }}$ edition, $453 \mathrm{p}$.

Mayr, E. \& Ashlock, P.D. (1991) Principles of systematic zoology. McGraw-Hill, 2nd ed. New York [etc.], pp. 54-74.

Matjašič, J. (1956a) Ein neuer Höhlenedecapode aus Jugoslawien. Zoologischer Anzeiger, 157 (3/4), 65-68.

Matjašič, J. (1956b) Eine neue Höhlengarnele aus Herzegowina. Bulletin scientifique, Jougoslavie, 3 (1), 8.

Matjašič, J. (1958) Postembrionalni razvoj jamske kozice Troglocaris. Biološki vestnik, VI, 76-79.

Matjašič, J. (1960) O vjetreniških troglokarisih (Über zwei Troglocaris-arten aus Vjetrenica). Biološki vestnik, 7, 75-80.

Milinkovitch, M.C. (1995) Molecular phylogeny of cetaceans prompts revision of morphological transformations. Trends in Ecology and Evolution, 10, 328-334.

Müller, G. (1931) Sopra crostacei delle nostre acque carsiche (Troglocaris Schmidti Dorm. e Sphaeromides Virei Brian). Atti del Museo Civico di Storia Naturale di Trieste, 11 (2), 206-216.

Pfenninger, M., Schwenk, K. (2007) Cryptic animal species are homogeneously distributed among taxa and biogeographical regions. BMC Evolutionary Biology, 7, 121 (6 p.)

Schlick-Steiner B.C., Seifert B., Stauffer C, Christian E., Crozier R.H., Steiner F.M. (2007) Without morphology, cryptic species stay in taxonomic crypsis following discovery. Trends in Ecology \& Evolution, 22 (8), 391-392.

Schluter, D. (2000) The ecology of adaptive radiation. Oxford Univ. Press, Oxford, NY .

Schutze, M.K., Jessup, A., Clarke, A.R. (2012) Wing shape as a potential discriminator of morphologically similar pest taxa within the Bactrocera dorsalis species complex (Diptera: Tephritidae). Bulletin of Entomological Research, 102 (1), 103-11.

Sket, B. (1985) Why all cave animals do not look alike - a discussion on adaptive value of reduction processes. The national speleological society Bulletin, 47 (2), 78-85.

Sket, B. (1992) Rdeči seznam ogroženih sladkovodnih višjih rakov (Malacostraca aquatica: Isopoda, Amphipoda, Decapoda) v Sloveniji (The Red Data List of endangered freshwater Malacostraca (Isopoda aquatica, Amphipoda, Decapoda) in Slovenia). Varstvo narave, 17, 147-156.

Sket, B. \& Zakšek, V. (2009) European cave shrimp species (Decapoda: Caridea: Atyidae), redefined after a phylogenetic study; redefinition of some taxa, a new genus and four new Troglocaris species. Zoological Journal of the Linnean Society, 155, $786-818$.

Silva de Oliveira D.A., Decraemer, W., Holovachov, O., Burr, J., De Ley, I.T, De Ley, P., Moens, T., Derycke, S. (2012) An integrative approach to characterize cryptic species in the Thoracostoma trachygaster Hope, 1967 complex (Nematoda: Leptosomatidae). Zoological Journal of Linnean Society, 164, 18-35.

Smith, K.L., Harmon, L.J., Shoo, L.P., Melville, J. (2011) Evidence of constrained phenotypic evolution in a cryptic species complex of agamid lizards. Evolution, 65, 976-992. doi: 10.1111/j.1558-5646.2010.01211.x

Thorpe, R.S. (1983) A review of the numerical methods for recognising and analysisng racial differenetiation. In: Numerical taxonomy (Felsenstein, J. ed). Springer Verlag, Berlin, p. 404-423.

Trape, J. F., Chirio, L., Broadley, D. G., Wüster, W. (2009) Phylogeography and systematic revision of the Egyptian cobra (Serpentes: Elapidae: Naja haje) species complex, with the description of a new species from West Africa. Zootaxa, 2236, 1-25.

D’Udekem d'Acoz, C. (1999) Inventaire et distribution des crustacés décapodes de l'Antique nord-oriental, de la Méditerranée et des eaux continentals adjacentes au nord de $25^{\circ}$ N. Patrimoines Naturels (MNHN/SPN), 40, Paris.

Whitfield J. 2007. Linnaeus at 300: We are family. Nature, 446, 247-249.

Zakšek, V., Sket, B., Trontelj, P. (2007) Phylogeny of the cave shrimp Troglocaris: evidence of a young connection between Balkans and Caucasus. Molecular Phylogenetics and Evolution, 42, 223-235.

Zakšek, V., Sket, B., Gottstein, S., Franjević, D., Trontelj, P. (2009) The limits of cryptic diversity in groundwater: phylogeography of the cave shrimp Troglocaris anophthalmus (Crustacea: Decapoda: Atyidae). Molecular Ecology, 18, 931-946. 
Appendix A. The results of Discriminant Function Analyses (DFAs) run on Troglocaris s. str. (a) males and (b) females.

(a) MALES: The principal result of DFA 1 (Figure A1) run on 156 males from four phylogroups of Troglocaris s. str. (adult males of $T$. (T.) bosnica were not available for the study), using 26 morphometric characters (Table A1), is the separation of all phylogroups. The classification error rate of the DFA 1 is only $3.2 \%$ (6.4\% for cross validation procedure). Each of three DFs separates at least one pair of phylogroups (Wilks' lambda, p < 0.001). DF 1-DF 3 account for $42.9 \%, 36.8 \%$ and $20.3 \%$ of the total variance, respectively. In the stepwise repetition with only 13 morphometric characters, the misclassification rate is $4.5 \%$ (for cross validation procedure 7.7 $\%$ ). The explained parts of total variance along DF 1-DF 3 are $43.7 \%, 38.3 \%$ and $17.9 \%$, respectively.

TABLE A1. Morphometric characters (MC) showing standardized discriminant function coefficients for all three discriminant functions (DFs), separately for non-stepwise and stepwise DFA 1, run on 156 males of T. (Troglocaris) from four phylogroups, using 26 and 13 characters, respectively. Meristic characters are written in italics. Largest absolute correlation between each MC and any DF is denoted with asterisk (»*«). For explanation of MCs' symbols, see taxonomic descriptions in the text.

\begin{tabular}{|c|c|c|c|c|c|c|c|c|c|c|c|c|}
\hline \multirow[t]{2}{*}{$\mathrm{MC}$} & \multicolumn{6}{|c|}{ Non-stepwise DFA } & \multicolumn{6}{|c|}{ Stepwise DFA } \\
\hline & DF 1 & & DF 2 & & DF 3 & & DF 1 & & DF 2 & & DF 3 & \\
\hline a13a12 & 0.558 & $*$ & -0.412 & & -0.243 & & 0.555 & $*$ & 0.525 & & -0.272 & \\
\hline $\mathrm{u} 21$ & 0.440 & $*$ & 0.159 & & -0.027 & & 0.499 & $*$ & -0.098 & & 0.011 & \\
\hline p5dp & 0.371 & $*$ & 0.031 & & 0.063 & & & & & & & \\
\hline $\mathrm{u} 2 \mathrm{cl}$ & 0.317 & $*$ & 0.036 & & -0.139 & & & & & & & \\
\hline $\mathrm{a} 2 \mathrm{~s} 2 \mathrm{~s} 1$ & 0.267 & $*$ & -0.167 & & -0.047 & & 0.267 & $*$ & 0.221 & & -0.046 & \\
\hline pr5pa & -0.237 & $*$ & 0.020 & & -0.066 & & & & & & & \\
\hline pr5ia & 0.211 & $*$ & -0.125 & & 0.209 & & 0.203 & & 0.175 & & 0.252 & $*$ \\
\hline tes1te 1 & 0.198 & $*$ & 0.099 & & -0.078 & & & & & & & \\
\hline te 1 s 6 & -0.132 & & -0.351 & $*$ & -0.145 & & -0.187 & & 0.350 & $*$ & -0.203 & \\
\hline pr1da & 0.082 & & -0.306 & $*$ & 0.083 & & & & & & & \\
\hline pr2pa & -0.032 & & -0.269 & $*$ & 0.197 & & -0.079 & & 0.288 & $*$ & 0.210 & \\
\hline ROT3 & -0.048 & & 0.244 & $*$ & -0.011 & & -0.017 & & -0.269 & $*$ & 0.001 & \\
\hline pr3da & -0.005 & & 0.222 & $*$ & -0.078 & & & & & & & \\
\hline pllenex & 0.079 & & 0.212 & $*$ & 0.001 & & 0.116 & & -0.214 & $*$ & 0.021 & \\
\hline a1s3an & 0.079 & & 0.202 & $*$ & -0.113 & & 0.118 & & -0.206 & $*$ & -0.113 & \\
\hline pr2pwcl & -0.021 & & -0.193 & $*$ & -0.037 & & & & & & & \\
\hline pr5ma & -0.151 & & 0.151 & $*$ & -0.147 & & & & & & & \\
\hline pr3ia & 0.161 & & -0.061 & & 0.405 & $*$ & & & & & & \\
\hline $\mathrm{a} 2 \mathrm{~s} 3 \mathrm{~s} 1$ & 0.160 & & 0.176 & & -0.386 & $*$ & 0.212 & & -0.173 & & -0.429 & $*$ \\
\hline pr2da & -0.002 & & -0.213 & & -0.363 & $*$ & -0.045 & & 0.238 & & 0.412 & $*$ \\
\hline$P 5 D$ & 0.057 & & 0.129 & & -0.322 & $*$ & & & & & & \\
\hline PPIENS & 0.018 & & 0.150 & & -0.303 & $*$ & 0.052 & & -0.167 & & -0.344 & $*$ \\
\hline prlim & 0.044 & & 0.069 & & 0.282 & $*$ & 0.047 & & -0.058 & & 0.339 & $*$ \\
\hline prlche & 0.055 & & -0.194 & & 0.243 & $*$ & & & & & & \\
\hline pr1ma & 0.014 & & 0.176 & & -0.220 & $*$ & & & & & & \\
\hline $\mathrm{s} 6 \mathrm{cl}$ & 0.134 & & 0.156 & & 0.183 & $*$ & & & & & & \\
\hline
\end{tabular}

(b) FEMALES: The principal result of DFA 2 (Figure A2) run on 289 females from five phylogroups of Troglocaris s. str., using 36 morphometric characters (Table A2), is in accordance with the result of DFA run on males. The classification error rate of the DFA is $7.6 \%$ (14.9\% for cross validation procedure). Each of all five DFs separate at least one pair of phylogroups (Wilks' lambda, p < 0.001). DF 1-DF 4 account for $47.6 \%, 23.0 \% ; 19.8 \%$ and $9.6 \%$ of the total variance, respectively. In the stepwise repetition with only 14 morphometric characters, the misclassification rate is $11.1 \%$ (for cross validation procedure $14.9 \%$ ) (Appendix B). The explained parts of total variance along DF 1-DF 4 are $49.8 \%, 24.6 \%, 19.0 \%$ and $6.5 \%$, respectively.

In an attempt to eliminate the impact of $14 T$. (T.) bosnica females on the other four phylogroups, DFA 3 (Figure A3) without T. (T.) bosnica, using 28 characters (Table A3) was run. The classification error rate is $7.3 \%$ (14.1\% for cross validation procedure). Each of four DFs separate at least one pair of phylogroups (Wilks' lambda, p < 0.001). DF 1-DF 3 account for $61.1 \%, 29.1 \%$ and $9.8 \%$ of the total variance, respectively. In the stepwise repetition with only 10 morphometric characters, the misclassification rate is $9.8 \%$ (for cross validation procedure $14.5 \%$ ). Percentages of the explained total variance along the DF 1-DF 3 are $60.5 \%, 32.0 \%$ and $7.5 \%$, respectively. 

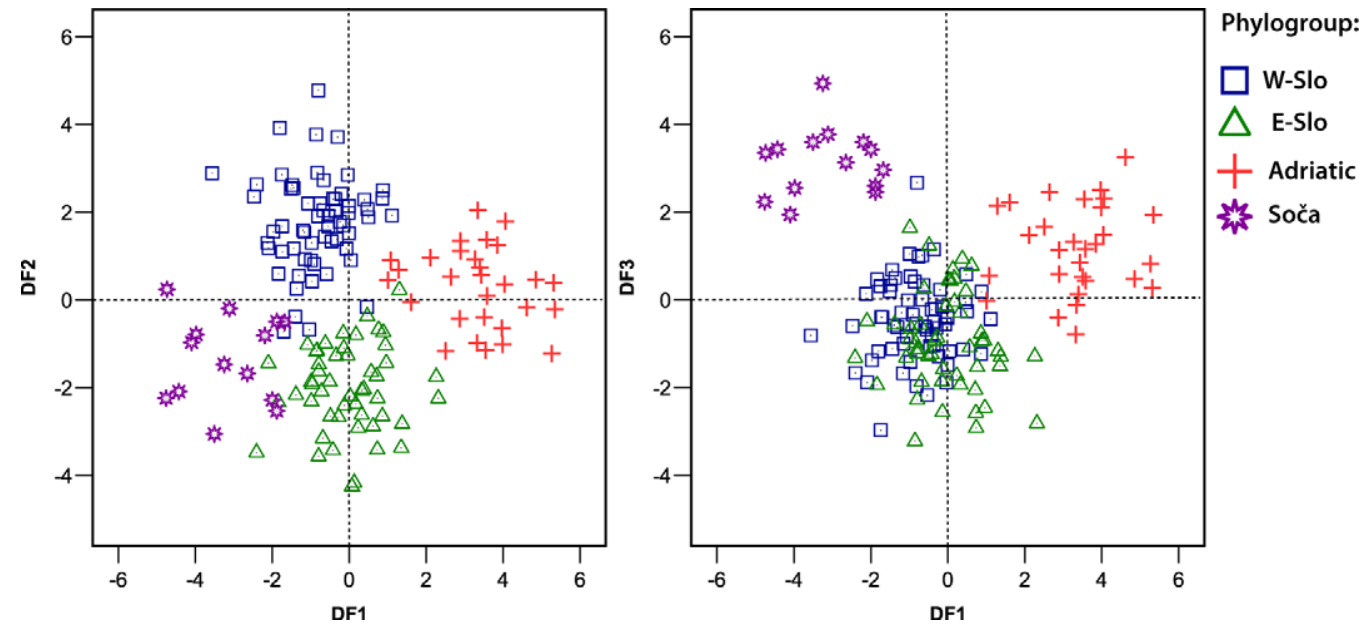

FIGURE A1. Plot of the DFA 1 scores of four phylogroups of $156 T$. sg. Troglocaris males on the all three discriminant functions (DF 1-DF 3), using 26 morphometric characters. W-Slo: T. (T.) planinensis; E-Slo: T. (T.) anophthalmus anophthalmus + T. (T.) a. ocellata ssp. nov. + T. (T.) a. intermedia; Adriatic: T. (T.) a. periadriatica ssp. nov.; Soča: $T$. (T.) $a$. sontica ssp. nov.
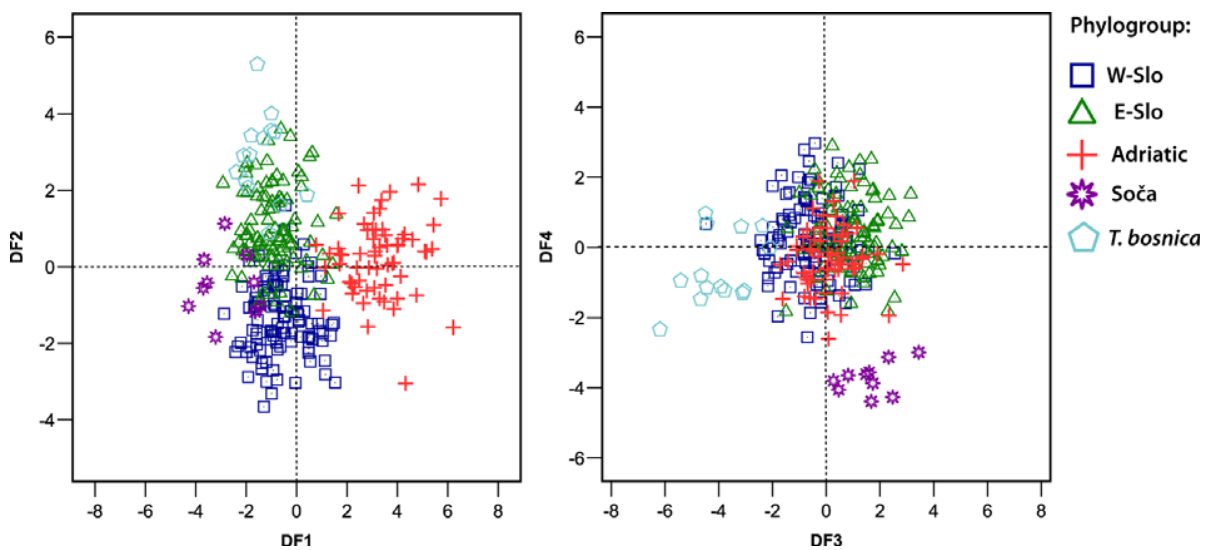

FIGURE A2. Plot of the DFA 2 scores of five phylogroups of 289 T. sg. Troglocaris females on the all four discriminant functions (DF 1-DF 4), using 36 morphometric characters. W-Slo: T. (T.) planinensis; E-Slo: T. (T.) anophthalmus anophthalmus $+T$. (T.) a. ocellata ssp. nov. + T. (T.) a. intermedia; Adriatic: T. (T.) a. periadriatica ssp. nov.; Soča: T. (T.) a. sontica ssp. nov.
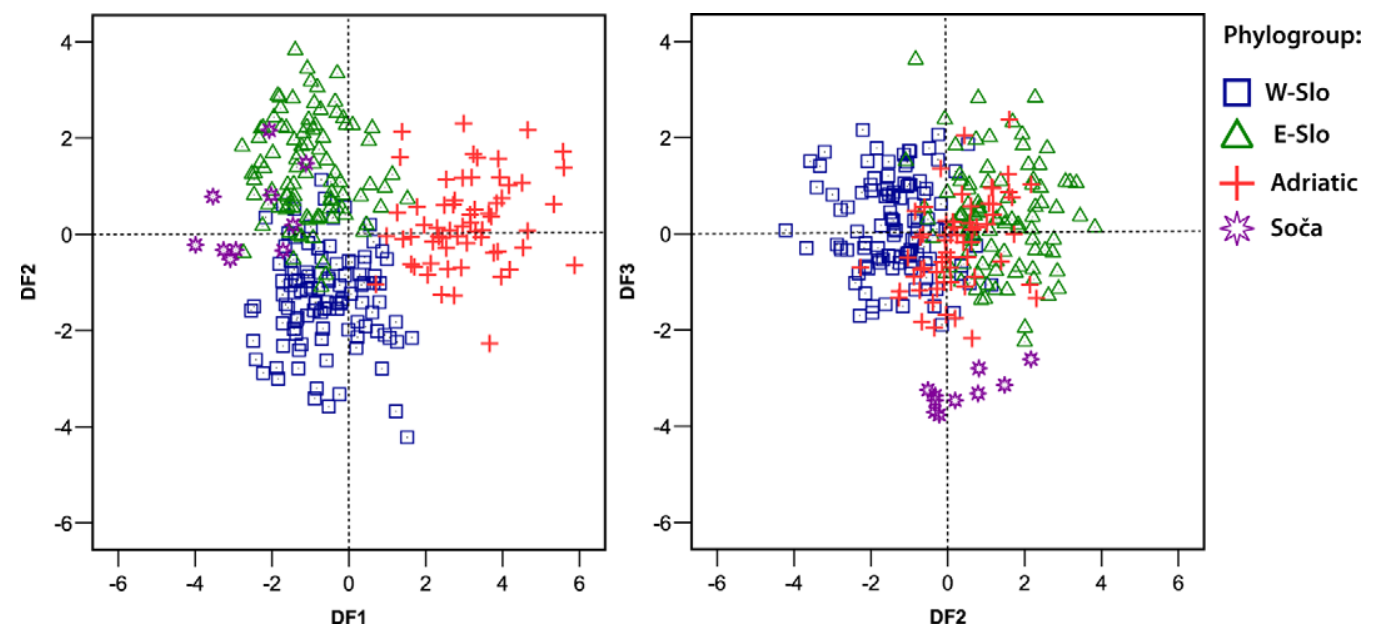

FIGURE A3. Plot of the DFA 3 scores of four phylogroups of 275 Troglocaris s. str. females (excluding T. (T.) bosnica) on the all three discriminant functions (DF 1- DF 3), using 28 morphometric characters. W-Slo: T. (T.) planinensis; E-Slo: T. (T.) anophthalmus anophthalmus + T. (T.) a. ocellata ssp. nov. + T. (T.) a. intermedia; Adriatic: T. (T.) a. periadriatica ssp. nov.; Soča: T. (T.) a. sontica ssp. nov. 
TABLE A2. Morphometric characters (MC) showing standardized discriminant function coefficients for all four discriminant functions (DFs), separately for non-stepwise and stepwise DFA 2, run on 289 females of T. (Troglocaris) from five phylogroups, using 36 and 14 characters, respectively. Meristic characters are written in italics. Largest absolute correlation between each MC and any DF is denoted with asterisk (»*«). For explanation of MCs’ symbols, see taxonomic descriptions in the text.

\begin{tabular}{|c|c|c|c|c|c|c|c|c|c|c|c|c|c|c|c|c|}
\hline \multirow[t]{2}{*}{$\mathrm{MC}$} & \multicolumn{8}{|c|}{ Non-stepwise DFA } & \multicolumn{8}{|c|}{ Stepwise DFA } \\
\hline & DF 1 & & DF 2 & & DF 3 & & DF 4 & & DF 1 & & DF 2 & & DF 3 & & DF 4 & \\
\hline tes2tes 1 & -0.370 & $*$ & 0.117 & & 0.233 & & -0.057 & & -0.408 & $*$ & 0.056 & & 0.326 & & -0.162 & \\
\hline u21 & 0.364 & $*$ & -0.048 & & -0.174 & & -0.043 & & 0.404 & $*$ & 0.006 & & -0.246 & & 0.013 & \\
\hline pr5da & 0.334 & $*$ & -0.130 & & -0.092 & & 0.048 & & & & & & & & & \\
\hline pr3da & 0.305 & $*$ & -0.068 & & 0.054 & & 0.000 & & 0.346 & $*$ & -0.067 & & 0.019 & & 0.039 & \\
\hline te $1 \mathrm{~s} 56$ & -0.258 & $*$ & 0.154 & & 0.100 & & 0.072 & & & & & & & & & \\
\hline a2s $2 \mathrm{~s} 1$ & 0.252 & $*$ & -0.131 & & 0.165 & & -0.015 & & 0.293 & $*$ & -0.162 & & 0.133 & & -0.001 & \\
\hline s56cl & 0.250 & $*$ & 0.120 & & -0.173 & & -0.142 & & 0.274 & $*$ & 0.183 & & -0.195 & & -0.145 & \\
\hline a1s1an & 0.188 & $*$ & -0.104 & & 0.068 & & -0.018 & & & & & & & & & \\
\hline a13a12 & 0.278 & & 0.597 & $*$ & 0.219 & & 0.321 & & 0.302 & & 0.622 & $*$ & 0.400 & & 0.445 & \\
\hline te $1 \mathrm{cl}$ & -0.018 & & 0.241 & $*$ & -0.061 & & -0.108 & & & & & & & & & \\
\hline pr5imcpd & -0.090 & & 0.236 & $*$ & -0.117 & & 0.015 & & & & & & & & & \\
\hline tes $2 \mathrm{cl}$ & -0.126 & & -0222 & $*$ & -0.074 & & -0.017 & & -0.149 & & 0.250 & $*$ & -0.017 & & -0.039 & \\
\hline pr1ma & -0.059 & & -0.187 & $*$ & -0.168 & & 0.134 & & & & & & & & & \\
\hline an $1 \mathrm{cl}$ & 0.115 & & 0.332 & & -0.404 & $*$ & -0.182 & & 0.110 & & 0.454 & $*$ & -0.396 & & -0.199 & \\
\hline prliccl & -0.022 & & 0.011 & & -0.386 & $*$ & -0.129 & & & & & & & & & \\
\hline ROTI & 0.018 & & 0.108 & & -0.332 & $*$ & -0.009 & & & & & & & & & \\
\hline pr2pplm & 0.036 & & -0.053 & & -0.316 & $*$ & -0.034 & & & & & & & & & \\
\hline $\mathrm{u} 2 \mathrm{cl}$ & 0.257 & & 0.095 & & -0.315 & $*$ & -0.049 & & & & & & & & & \\
\hline pr5ma & -0.194 & & 0.298 & & -0.312 & $*$ & 0.009 & & -0.237 & & 0.379 & $*$ & -0.264 & & 0.013 & \\
\hline pr1plma & 0.038 & & 0.198 & & 0.312 & $*$ & -0.168 & & 0.055 & & 0.153 & & 0.397 & $*$ & -0.270 & \\
\hline $\mathrm{rcl}$ & -0.011 & & 0.125 & & -0.293 & $*$ & -0.114 & & & & & & & & & \\
\hline u1te1 & 0.040 & & -0.115 & & -0.269 & $*$ & 0.255 & & 0.031 & & -0.067 & & -0.329 & & 0.395 & * \\
\hline a11an & -0.142 & & -0.089 & & 0.240 & $*$ & -0.065 & & & & & & & & & \\
\hline pllenex & 0.055 & & -0.204 & & 0.228 & $*$ & 0.180 & & 0.072 & & -0.267 & $*$ & 0.213 & & 0.237 & \\
\hline pr2pa & 0.013 & & 0.201 & & 0.219 & $*$ & -0.150 & & & & & & & & & \\
\hline pr5ia & 0.121 & & -0.066 & & 0.217 & $*$ & 0.002 & & & & & & & & & \\
\hline a1s3an & 0.107 & & -0.045 & & -0.198 & $*$ & 0.117 & & & & & & & & & \\
\hline pr5pa & -0.122 & & -0.170 & & 0.172 & $*$ & 0.036 & & & & & & & & & \\
\hline pr2da & 0.114 & & 0.221 & & 0.172 & & -0.353 & $*$ & & & & & & & & \\
\hline $\mathrm{a} 2 \mathrm{~s} 3 \mathrm{~s} 1$ & 0.107 & & -0.059 & & -0.116 & & 0.314 & $*$ & & & & & & & & \\
\hline$P 5 D$ & 0.130 & & -0.177 & & -0.159 & & 0.303 & $*$ & & & & & & & & \\
\hline pr1da & 0.156 & & 0.261 & & 0.221 & & -0.301 & $*$ & 0.186 & & 0.248 & & 0.293 & & -0.430 & * \\
\hline pr1che & 0.030 & & 0.225 & & -0.062 & & -0.279 & $*$ & & & & & & & & \\
\hline u1s56 & -0.209 & & 0.057 & & -0.098 & & 0.272 & $*$ & -0.246 & & 0.069 & & -0.066 & & 0.359 & $*$ \\
\hline pl2aicl & -0.021 & & 0.145 & & -0.137 & & 0.230 & $*$ & & & & & & & & \\
\hline pr2dplm & 0.110 & & 0.023 & & -0.144 & & -0.214 & $*$ & & & & & & & & \\
\hline
\end{tabular}


TABLE A3. Morphological characters (MC) showing standardized discriminant function coefficients for all three discriminant functions (DFs), separately for non-stepwise and stepwise DFA 3, run on 275 females of the subgenus Troglocaris from four phylogroups, using 28 and 10 characters, respectively. Meristic characters are written in italics. Largest absolute correlation between each MC and any DF is denoted with asterisk (»*«). For explanation of MCs’ symbols, see taxonomic descriptions in the text.

\begin{tabular}{|c|c|c|c|c|c|c|c|c|c|c|c|c|}
\hline \multirow{3}{*}{$\begin{array}{l}\text { MC } \\
\text { tes2tes1 }\end{array}$} & \multicolumn{6}{|c|}{ Non-stepwise DFA } & \multicolumn{6}{|c|}{ Stepwise DFA } \\
\hline & \multicolumn{2}{|l|}{ DF 1} & \multicolumn{2}{|l|}{ DF 2} & \multicolumn{2}{|l|}{ DF 3} & \multicolumn{2}{|l|}{ DF 1} & \multicolumn{2}{|l|}{ DF 2} & \multicolumn{2}{|l|}{ DF 3} \\
\hline & 0.409 & $*$ & 0.222 & & -0.146 & & -0.467 & $*$ & 0.249 & & -0.134 & \\
\hline u21 & 0.392 & $*$ & -0.128 & & 0.022 & & 0.445 & $*$ & -0.151 & & -0.035 & \\
\hline pr5da & 0.346 & $*$ & -0.152 & & 0.087 & & 0.394 & $*$ & -0.173 & & 0.061 & \\
\hline $\mathrm{u} 2 \mathrm{cl}$ & 0.325 & $*$ & -0.080 & & 0.195 & & & & & & & \\
\hline pr3da & 0.305 & $*$ & -0.020 & & -0.002 & & & & & & & \\
\hline s56cl & 0.292 & $*$ & 0.027 & & -0.079 & & 0.331 & $*$ & 0.016 & & -0.164 & \\
\hline te1s56 & -0.289 & $*$ & 0.196 & & 0.063 & & & & & & & \\
\hline $\mathrm{a} 2 \mathrm{~s} 2 \mathrm{~s} 1$ & 0.237 & $*$ & -0.019 & & -0.066 & & & & & & & \\
\hline an $1 \mathrm{cl}$ & 0.204 & $*$ & 0.089 & & -0.036 & & & & & & & \\
\hline a1s1an & 0.182 & $*$ & -0.042 & & -0.045 & & & & & & & \\
\hline a11an & -0.174 & $*$ & 0.046 & & -0.170 & & & & & & & \\
\hline pr5pa & -0.158 & $*$ & -0.063 & & -0.046 & & & & & & & \\
\hline pr5ma & -0.152 & $*$ & 0.086 & & 0.134 & & -0.168 & & 0.103 & & 0.194 & $*$ \\
\hline a13a12 & 0.295 & & 0.676 & $*$ & 0.437 & & 0.358 & & 0.735 & $*$ & 0.425 & \\
\hline pr1da & 0.162 & & 0.358 & $*$ & -0.354 & & 0.180 & & 0.369 & & -0.535 & $*$ \\
\hline pr1plma & 0.023 & & 0.341 & $*$ & -0.246 & & & & & & & \\
\hline pr2pa & 0.006 & & 0.292 & $*$ & -0.201 & & 0.006 & & 0.309 & $*$ & -0.296 & \\
\hline pr1ma & -0.058 & & -0.255 & $*$ & 0.168 & & & & & & & \\
\hline pr2pplm & 0.067 & & -0.218 & $*$ & 0.045 & & & & & & & \\
\hline tes $2 \mathrm{cl}$ & -0.115 & & 0.163 & $*$ & 0.029 & & -0.128 & & 0.181 & $*$ & 0.041 & \\
\hline pr2da & 0.123 & & 0.287 & & -0.411 & $*$ & & & & & & \\
\hline $\mathrm{a} 2 \mathrm{~s} 3 \mathrm{~s} 1$ & 0.111 & & -0.103 & & 0.395 & $*$ & & & & & & \\
\hline$P 5 D$ & 0.131 & & -0.233 & & 0.375 & $*$ & & & & & & \\
\hline u1te1 & 0.054 & & -0.245 & & 0.356 & $*$ & 0.068 & & -0.255 & & 0.481 & $*$ \\
\hline u1s56 & -0.221 & & -0.009 & & 0.351 & $*$ & & & & & & \\
\hline prlche & 0.063 & & 0.178 & & -0.285 & $*$ & & & & & & \\
\hline pr2dplm & 0.135 & & -0.056 & & -0.193 & $*$ & & & & & & \\
\hline a1s3an & 0.124 & & -0.140 & & 0.193 & $*$ & & & & & & \\
\hline
\end{tabular}

Appendix B. Tables of descriptive statistics (mean, standard deviation, minimum, maximum) of the phylogroups, separately for males and females.

Appendix B1. Morphometric comparison of five phylogroups of $T$. sg. Troglocaris adult males. MC - morphometric character; number of specimens measured for each MC in superscript. Carapace length (CL) and MCs used in DFA 1, are listed (MCs, used in the stepwise repetition of DFA 1, are denoted with asterisk; scarce samples of the Istra phylogroup were excluded from DFA). Upper line: arithmetic mean $\pm 1 \mathrm{SD}$; lower line [minimum, maximum]. Abbreviations of MCs as in Appendix A; for explanation of MCs' symbols, see taxonomic descriptions in the text. Istra - data for holotype male only. 


\begin{tabular}{|c|c|c|c|c|c|}
\hline $\mathrm{MC}$ & $\begin{array}{l}\text { W- Slo } \\
\text { (T. planinensis) }\end{array}$ & $\begin{array}{l}\text { E-Slo } \\
\text { (T. a. anophthalmus + } \\
\text { T. a. ocellata }+ \\
\text { T. a. intermedia })\end{array}$ & $\begin{array}{l}\text { Adriatic } \\
\text { (T. a. periadriatica) }\end{array}$ & $\begin{array}{l}\text { Soča } \\
(T . \text { a. sontica })\end{array}$ & $\begin{array}{l}\text { Istra } \\
\text { (T. a. legovici) }\end{array}$ \\
\hline $\mathrm{CL}$ & $\begin{array}{l}6.61 \pm 0.75^{62} \\
{[5.12,8.18]}\end{array}$ & $\begin{array}{l}6.3 \pm 0.75^{50} \\
{[4.73,8.33]}\end{array}$ & $\begin{array}{l}5.96 \pm 0.6^{29} \\
{[4.75,7.26]}\end{array}$ & $\begin{array}{l}5.77 \pm 0.47^{14} \\
{[5,6.83]}\end{array}$ & 5.70 \\
\hline ROT3 & $\begin{array}{l}4.97 \pm 2.49^{58} \\
{[0,11]}\end{array}$ & $\begin{array}{l}2.76 \pm 2.46^{45} \\
{[0,12]}\end{array}$ & $\begin{array}{l}3.71 \pm 1.76^{24} \\
{[0,9]}\end{array}$ & $\begin{array}{l}3.36 \pm 2.24^{14} \\
{[0,7]}\end{array}$ & 4 \\
\hline a1s3an & $\begin{array}{l}0.15 \pm 0.02^{60} \\
{[0.12,0.2]}\end{array}$ & $\begin{array}{l}0.14 \pm 0.02^{49} \\
{[0.09,0.18]}\end{array}$ & $\begin{array}{l}0.15 \pm 0.02^{29} \\
{[0.12,0.19]}\end{array}$ & $\begin{array}{l}0.13 \pm 0.02^{14} \\
{[0.1,0.17]}\end{array}$ & 0.14 \\
\hline a13a12 & $\begin{array}{l}0.44 \pm 0.05^{62} \\
{[0.33,0.57]}\end{array}$ & $\begin{array}{l}0.56 \pm 0.06^{50} \\
{[0.44,0.7]}\end{array}$ & $\begin{array}{l}0.58 \pm 0.06^{29} \\
{[0.46,0.73]}\end{array}$ & $\begin{array}{l}0.39 \pm 0.04^{14} \\
{[0.33,0.46]}\end{array}$ & 0.50 \\
\hline $\mathrm{a} 2 \mathrm{~s} 3 \mathrm{~s} 1$ & $\begin{array}{l}0.11 \pm 0.02^{60} \\
{[0.07,0.14]}\end{array}$ & $\begin{array}{l}0.1 \pm 0.02^{49} \\
{[0.07,0.13]}\end{array}$ & $\begin{array}{l}0.1 \pm 0.01^{28} \\
{[0.08,0.13]}\end{array}$ & $\begin{array}{l}0.07 \pm 0.01^{14} \\
{[0.05,0.1]}\end{array}$ & 0.10 \\
\hline $\mathrm{a} 2 \mathrm{~s} 2 \mathrm{~s} 1$ & $\begin{array}{l}0.35 \pm 0.03^{62} \\
{[0.28,0.41]}\end{array}$ & $\begin{array}{l}0.37 \pm 0.02^{49} \\
{[0.31,0.41]}\end{array}$ & $\begin{array}{l}0.38 \pm 0.02^{29} \\
{[0.33,0.42]}\end{array}$ & $\begin{array}{l}0.34 \pm 0.02^{14} \\
{[0.31,0.38]}\end{array}$ & 0.34 \\
\hline pr1ma & $\begin{array}{l}0.24 \pm 0.01^{62} \\
{[0.22,0.28]}\end{array}$ & $\begin{array}{l}0.24 \pm 0.01^{50} \\
{[0.2,0.27]}\end{array}$ & $\begin{array}{l}0.24 \pm 0.02^{29} \\
{[0.2,0.26]}\end{array}$ & $\begin{array}{l}0.23 \pm 0.02^{14} \\
{[0.2,0.25]}\end{array}$ & 0.26 \\
\hline pr1da & $\begin{array}{l}0.2 \pm 0.02^{62} \\
{[0.16,0.24]}\end{array}$ & $\begin{array}{l}0.22 \pm 0.02^{50} \\
{[0.18,0.25]}\end{array}$ & $\begin{array}{l}0.21 \pm 0.01^{29} \\
{[0.18,0.23]}\end{array}$ & $\begin{array}{l}0.21 \pm 0.02^{14} \\
{[0.19,0.24]}\end{array}$ & 0.17 \\
\hline priche & $\begin{array}{l}0.23 \pm 0.02^{62} \\
{[0.19,0.28]}\end{array}$ & $\begin{array}{l}0.24 \pm 0.02^{50} \\
{[0.19,0.3]}\end{array}$ & $\begin{array}{l}0.25 \pm 0.02^{29} \\
{[0.22,0.27]}\end{array}$ & $\begin{array}{l}0.26 \pm 0.02^{14} \\
{[0.22,0.29]}\end{array}$ & 0.22 \\
\hline prlim & $\begin{array}{l}0.88 \pm 0.07^{62} \\
{[0.73,1.03]}\end{array}$ & $\begin{array}{l}0.86 \pm 0.06^{50} \\
{[0.69,0.98]}\end{array}$ & $\begin{array}{l}0.92 \pm 0.05^{28} \\
{[0.81,0.99]}\end{array}$ & $\begin{array}{l}0.93 \pm 0.05^{14} \\
{[0.81,1]}\end{array}$ & 0.96 \\
\hline pr2pa & $\begin{array}{l}0.24 \pm 0.02^{61} \\
{[0.21,0.29]}\end{array}$ & $\begin{array}{l}0.25 \pm 0.01^{50} \\
{[0.22,0.29]}\end{array}$ & $\begin{array}{l}0.25 \pm 0.01^{28} \\
{[0.22,0.27]}\end{array}$ & $\begin{array}{l}0.26 \pm 0.02^{13} \\
{[0.24,0.3]}\end{array}$ & 0.20 \\
\hline pr2da & $\begin{array}{l}0.16 \pm 0.01^{61} \\
{[0.14,0.2]}\end{array}$ & $\begin{array}{l}0.17 \pm 0.01^{50} \\
{[0.15,0.21]}\end{array}$ & $\begin{array}{l}0.17 \pm 0.01^{28} \\
{[0.15,0.2]}\end{array}$ & $\begin{array}{l}0.19 \pm 0.01^{13} \\
{[0.17,0.21]}\end{array}$ & 0.16 \\
\hline pr2pwcl & $\begin{array}{l}0.08 \pm 0.02^{62} \\
{[0.05,0.13]}\end{array}$ & $\begin{array}{l}0.1 \pm 0.02^{50} \\
{[0.06,0.14]}\end{array}$ & $\begin{array}{l}0.09 \pm 0.01^{28} \\
{[0.07,0.12]}\end{array}$ & $\begin{array}{l}0.09 \pm 0.02^{13} \\
{[0.07,0.13]}\end{array}$ & 0.08 \\
\hline pr3ia & $\begin{array}{l}0.08 \pm 0.01^{62} \\
{[0.07,0.1]}\end{array}$ & $\begin{array}{l}0.08 \pm 0.01^{44} \\
{[0.07,0.1]}\end{array}$ & $\begin{array}{l}0.1 \pm 0.01^{28} \\
{[0.08,0.11]}\end{array}$ & $\begin{array}{l}0.09 \pm 0.01^{14} \\
{[0.08,0.11]}\end{array}$ & 0.10 \\
\hline pr3da & $\begin{array}{l}0.11 \pm 0.02^{62} \\
{[0.06,0.14]}\end{array}$ & $\begin{array}{l}0.1 \pm 0.02^{44} \\
{[0.05,0.13]}\end{array}$ & $\begin{array}{l}0.1 \pm 0.01^{28} \\
{[0.08,0.12]}\end{array}$ & $\begin{array}{l}0.09 \pm 0.01^{14} \\
{[0.07,0.12]}\end{array}$ & 0.10 \\
\hline pr5ia & $\begin{array}{l}0.09 \pm 0.01^{58} \\
{[0.07,0.1]}\end{array}$ & $\begin{array}{l}0.09 \pm 0.01^{44} \\
{[0.08,0.1]}\end{array}$ & $\begin{array}{l}0.09 \pm 0.01^{28} \\
{[0.08,0.11]}\end{array}$ & $\begin{array}{l}0.09 \pm 0.01^{12} \\
{[0.08,0.1]}\end{array}$ & 0.10 \\
\hline pr5ma & $\begin{array}{l}0.3 \pm 0.01^{58} \\
{[0.28,0.32]}\end{array}$ & $\begin{array}{l}0.3 \pm 0.01^{44} \\
{[0.28,0.32]}\end{array}$ & $\begin{array}{l}0.29 \pm 0.01^{28} \\
{[0.28,0.31]}\end{array}$ & $\begin{array}{l}0.3 \pm 0.01^{12} \\
{[0.28,0.3]}\end{array}$ & 0.30 \\
\hline pr5pa & $\begin{array}{l}0.36 \pm 0.01^{58} \\
{[0.34,0.38]}\end{array}$ & $\begin{array}{l}0.36 \pm 0.01^{44} \\
{[0.34,0.38]}\end{array}$ & $\begin{array}{l}0.35 \pm 0.01^{28} \\
{[0.33,0.37]}\end{array}$ & $\begin{array}{l}0.36 \pm 0.01^{12} \\
{[0.34,0.38]}\end{array}$ & 0.37 \\
\hline $\mathrm{p} 5 \mathrm{dp}$ & $\begin{array}{l}0.22 \pm 0.02^{58} \\
{[0.18,0.26]}\end{array}$ & $\begin{array}{l}0.23 \pm 0.02^{44} \\
{[0.19,0.26]}\end{array}$ & $\begin{array}{l}0.25 \pm 0.02^{28} \\
{[0.21,0.28]}\end{array}$ & $\begin{array}{l}0.21 \pm 0.02^{12} \\
{[0.17,0.25]}\end{array}$ & 0.18 \\
\hline$P 5 D$ & $\begin{array}{l}46.64 \pm 7.04^{56} \\
{[34,60]}\end{array}$ & $\begin{array}{l}45.54 \pm 5.12^{43} \\
{[37,56]}\end{array}$ & $\begin{array}{l}44.07 \pm 5.4^{28} \\
{[31,56]}\end{array}$ & $\begin{array}{l}36.83 \pm 4.28^{12} \\
{[32,47]}\end{array}$ & 30 \\
\hline pllenex & $\begin{array}{l}0.41 \pm 0.04^{61} \\
{[0.32,0.52]}\end{array}$ & $\begin{array}{l}0.38 \pm 0.03^{47} \\
{[0.33,0.48]}\end{array}$ & $\begin{array}{l}0.41 \pm 0.03^{28} \\
{[0.37,0.46]}\end{array}$ & $\begin{array}{l}0.38 \pm 0.02^{13} \\
{[0.34,0.41]}\end{array}$ & 0.42 \\
\hline PPIENS & $\begin{array}{l}25.97 \pm 4.97^{62} \\
{[16,40]}\end{array}$ & $\begin{array}{l}24.1 \pm 3.63^{48} \\
{[12,33]}\end{array}$ & $\begin{array}{l}23.1 \pm 4.98^{29} \\
{[14,38]}\end{array}$ & $\begin{array}{l}18.86 \pm 2.83^{14} \\
{[15,24]}\end{array}$ & 21 \\
\hline s6cl & $\begin{array}{l}0.56 \pm 0.04^{62} \\
{[0.46,0.64]}\end{array}$ & $\begin{array}{l}0.54 \pm 0.04^{50} \\
{[0.44,0.61]}\end{array}$ & $\begin{array}{l}0.59 \pm 0.03^{29} \\
{[0.52,0.67]}\end{array}$ & $\begin{array}{l}0.55 \pm 0.02^{14} \\
{[0.53,0.58]}\end{array}$ & 0.50 \\
\hline te $1 \mathrm{~s} 6$ & $\begin{array}{l}0.91 \pm 0.07^{56} \\
{[0.75,1.06]}\end{array}$ & $\begin{array}{l}0.99 \pm 0.06^{44} \\
{[0.84,1.11]}\end{array}$ & $\begin{array}{l}0.89 \pm 0.06^{25} \\
{[0.76,1.03]}\end{array}$ & $\begin{array}{l}0.97 \pm 0.05^{12} \\
{[0.89,1.03]}\end{array}$ & 0.97 \\
\hline tes 1 te 1 & $\begin{array}{l}0.43 \pm 0.06^{56} \\
{[0.3,0.53]}\end{array}$ & $\begin{array}{l}0.42 \pm 0.05^{44} \\
{[0.32,0.5]}\end{array}$ & $\begin{array}{l}0.45 \pm 0.05^{25} \\
{[0.37,0.6]}\end{array}$ & $\begin{array}{l}0.37 \pm 0.05^{11} \\
{[0.3,0.4]}\end{array}$ & 0.37 \\
\hline $\mathrm{u} 2 \mathrm{cl}$ & $\begin{array}{l}0.18 \pm 0.02^{60} \\
{[0.15,0.23]}\end{array}$ & $\begin{array}{l}0.19 \pm 0.02^{46} \\
{[0.15,0.22]}\end{array}$ & $\begin{array}{l}0.2 \pm 0.02^{27} \\
{[0.17,0.24]}\end{array}$ & $\begin{array}{l}0.16 \pm 0.011^{13} \\
{[0.14,0.18]}\end{array}$ & 0.19 \\
\hline u21 & $\begin{array}{l}0.32 \pm 0.02^{59} \\
{[0.28,0.36]}\end{array}$ & $\begin{array}{l}0.32 \pm 0.01^{46} \\
{[0.28,0.35]}\end{array}$ & $\begin{array}{l}0.35 \pm 0.02^{27} \\
{[0.32,0.39]}\end{array}$ & $\begin{array}{l}0.29 \pm 0.02^{13} \\
{[0.27,0.32]}\end{array}$ & 0.29 \\
\hline
\end{tabular}


Appendix B2. Morphometric comparison of six (DFA 2) and five (DFA 3) phylogroups of T. sg. Troglocaris adult females. MC - morphometric character; number of specimens measured for each MC in superscript. Carapace length (CL) and MCs used in DFA 2 and DFA 3, are listed (MCs, used in the stepwise repetition of DFA 1 and DFA 2 are denoted with asterisks; scarce samples of the Istra phylogroup were excluded from DFAs). Upper line: arithmetic mean \pm 1 SD; lower line [minimum, maximum]. Abbreviations of MCs as in Appendix A; for explanation of MCs' symbols, see taxonomic descriptions in the text.

\begin{tabular}{|c|c|c|c|c|c|c|c|c|}
\hline $\mathrm{MC}$ & $\begin{array}{l}\text { W- Slo } \\
\text { (T. planinensis) }\end{array}$ & $\begin{array}{l}\text { E-Slo } \\
\text { (T. a. } \\
\text { anophthalmus + } \\
\text { T. a. ocellata + } \\
\text { T. a. intermedia) }\end{array}$ & $\begin{array}{l}\text { Adriatic } \\
\text { (T. a. periadri- } \\
\text { atica) }\end{array}$ & $\begin{array}{l}\text { Soča } \\
(T . \text { a. sontica })\end{array}$ & $\begin{array}{l}\text { Istra } \\
(T . a . \\
\text { legovici) }\end{array}$ & T. bosnica & DFA 2 & DFA 3 \\
\hline$\overline{\mathrm{CL}}$ & $\begin{array}{l}7.79 \pm 0.911^{106} \\
{[5.51,9.93]}\end{array}$ & $\begin{array}{l}7.31 \pm 0.84^{95} \\
{[5.83,8.99]}\end{array}$ & $\begin{array}{l}6.91 \pm 0.73^{61} \\
{[5.2,8.65]}\end{array}$ & $\begin{array}{l}6.49 \pm 0.38^{10} \\
{[5.9,7.02]}\end{array}$ & $6.2^{1}$ & $\begin{array}{l}6.71 \pm 1.08^{14} \\
{[5.1,8.8]}\end{array}$ & & \\
\hline $\mathrm{rcl}$ & $\begin{array}{l}0.5 \pm 0.14^{94} \\
{[0.23,0.86]}\end{array}$ & $\begin{array}{l}0.49 \pm 0.14{ }^{90} \\
{[0.16,0.8]}\end{array}$ & $\begin{array}{l}0.51 \pm 0.07^{58} \\
{[0.28,0.66]}\end{array}$ & $\begin{array}{l}0.49 \pm 0.08^{10} \\
{[0.35,0.59]}\end{array}$ & $0.34^{1}$ & $\begin{array}{l}0.71 \pm 0.15^{8} \\
{[0.56,0.96]}\end{array}$ & + & \\
\hline ROT1 & $\begin{array}{l}19.62 \pm 3.67^{92} \\
{[11,29]}\end{array}$ & $\begin{array}{l}18.77 \pm 5.73^{90} \\
{[5,30]}\end{array}$ & $\begin{array}{l}19.97 \pm 3.77^{58} \\
{[13,37]}\end{array}$ & $\begin{array}{l}16.8 \pm 8.18^{10} \\
{[0,22]}\end{array}$ & $17^{1}$ & $\begin{array}{l}27.25 \pm 2.38^{8} \\
{[25,32]}\end{array}$ & + & \\
\hline an $1 \mathrm{cl}$ & $\begin{array}{l}0.45 \pm 0.04^{105} \\
{[0.36,0.55]}\end{array}$ & $\begin{array}{l}0.46 \pm 0.03^{95} \\
{[0.39,0.57]}\end{array}$ & $\begin{array}{l}0.49 \pm 0.03^{61} \\
{[0.4,0.54]}\end{array}$ & $\begin{array}{l}0.45 \pm 0.02^{10} \\
{[0.43,0.48]}\end{array}$ & $0.46^{1}$ & $\begin{array}{l}0.56 \pm 0.08^{14} \\
{[0.45,0.74]}\end{array}$ & $+/ *$ & + \\
\hline a11an & $\begin{array}{l}0.5 \pm 0.02^{105} \\
{[0.45,0.54]}\end{array}$ & $\begin{array}{l}0.5 \pm 0.02^{95} \\
{[0.46,0.53]}\end{array}$ & $\begin{array}{l}0.49 \pm 0.02^{61} \\
{[0.45,0.54]}\end{array}$ & $\begin{array}{l}0.52 \pm 0.01^{10} \\
{[0.49,0.54]}\end{array}$ & $0.47^{1}$ & $\begin{array}{l}0.48 \pm 0.01^{14} \\
{[0.45,0.5]}\end{array}$ & + & + \\
\hline a1s1an & $\begin{array}{l}0.44 \pm 0.03^{104} \\
{[0.37,0.5]}\end{array}$ & $\begin{array}{l}0.44 \pm 0.03^{95} \\
{[0.37,0.52]}\end{array}$ & $\begin{array}{l}0.46 \pm 0.03^{61} \\
{[0.4,0.56]}\end{array}$ & $\begin{array}{l}0.43 \pm 0.03^{10} \\
{[0.4,0.48]}\end{array}$ & $0.43^{1}$ & $\begin{array}{l}0.42 \pm 0.02^{14} \\
{[0.38,0.45]}\end{array}$ & + & + \\
\hline a1s3an & $\begin{array}{l}0.15 \pm 0.02^{105} \\
{[0.1,0.19]}\end{array}$ & $\begin{array}{l}0.15 \pm 0.02^{95} \\
{[0.1,0.21]}\end{array}$ & $\begin{array}{l}0.16 \pm 0.02^{61} \\
{[0.11,0.21]}\end{array}$ & $\begin{array}{l}0.13 \pm 0.03^{10} \\
{[0.08,0.18]}\end{array}$ & $0.13^{1}$ & $\begin{array}{l}0.16 \pm 0.01^{14} \\
{[0.13,0.19]}\end{array}$ & + & + \\
\hline a13a12 & $\begin{array}{l}0.43 \pm 0.05^{106} \\
{[0.31,0.58]}\end{array}$ & $\begin{array}{l}0.53 \pm 0.06^{95} \\
{[0.41,0.68]}\end{array}$ & $\begin{array}{l}0.55 \pm 0.06^{61} \\
{[0.44,0.69]}\end{array}$ & $\begin{array}{l}0.38 \pm 0.07^{10} \\
{[0.31,0.5]}\end{array}$ & $0.53^{1}$ & $\begin{array}{l}0.51 \pm 0.07^{14} \\
{[0.39,0.61]}\end{array}$ & $+/ *$ & $+/ *$ \\
\hline $\mathrm{a} 2 \mathrm{~s} 3 \mathrm{~s} 1$ & $\begin{array}{l}0.11 \pm 0.02^{105} \\
{[0.07,0.15]}\end{array}$ & $\begin{array}{l}0.1 \pm 0.011^{95} \\
{[0.07,0.13]}\end{array}$ & $\begin{array}{l}0.11 \pm 0.02^{61} \\
{[0.07,0.14]}\end{array}$ & $\begin{array}{l}0.08 \pm 0.01^{10} \\
{[0.06,0.09]}\end{array}$ & $0.10^{1}$ & $\begin{array}{l}0.10 \pm 0.02^{14} \\
{[0.08,0.13]}\end{array}$ & + & + \\
\hline $\mathrm{a} 2 \mathrm{~s} 2 \mathrm{~s} 1$ & $\begin{array}{l}0.37 \pm 0.03^{105} \\
{[0.3,0.42]}\end{array}$ & $\begin{array}{l}0.36 \pm 0.02^{95} \\
{[0.29,0.44]}\end{array}$ & $\begin{array}{l}0.39 \pm 0.03{ }^{61} \\
{[0.32,0.47]}\end{array}$ & $\begin{array}{l}0.36 \pm 0.02^{10} \\
{[0.3,0.38]}\end{array}$ & $0.35^{1}$ & $\begin{array}{l}0.33 \pm 0.02^{14} \\
{[0.29,0.37]}\end{array}$ & $+/ *$ & + \\
\hline pr1iccl & $\begin{array}{l}0.43 \pm 0.04^{105} \\
{[0.35,0.56]}\end{array}$ & $\begin{array}{l}0.41 \pm 0.04{ }^{95} \\
{[0.34,0.49]}\end{array}$ & $\begin{array}{l}0.42 \pm 0.03^{61} \\
{[0.37,0.51]}\end{array}$ & $\begin{array}{l}0.42 \pm 0.02^{10} \\
{[0.38,0.45]}\end{array}$ & - & $\begin{array}{l}0.49 \pm 0.07^{14} \\
{[0.42,0.66]}\end{array}$ & + & + \\
\hline pr1ma & $\begin{array}{l}0.25 \pm 0.02^{105} \\
{[0.21,0.29]}\end{array}$ & $\begin{array}{l}0.24 \pm 0.01{ }^{95} \\
{[0.21,0.28]}\end{array}$ & $\begin{array}{l}0.24 \pm 0.02^{61} \\
{[0.2,0.26]}\end{array}$ & $\begin{array}{l}0.23 \pm 0.01^{10} \\
{[0.22,0.25]}\end{array}$ & - & $\begin{array}{l}0.24 \pm 0.022^{14} \\
{[0.22,0.27]}\end{array}$ & + & + \\
\hline pr1plma & $\begin{array}{l}0.36 \pm 0.04^{105} \\
{[0.31,0.45]}\end{array}$ & $\begin{array}{l}0.38 \pm 0.02^{95} \\
{[0.34,0.43]}\end{array}$ & $\begin{array}{l}0.38 \pm 0.02^{61} \\
{[0.34,0.43]}\end{array}$ & $\begin{array}{l}0.4 \pm 0.02^{10} \\
{[0.37,0.43]}\end{array}$ & - & $\begin{array}{l}0.36 \pm 0.02^{14} \\
{[0.33,0.38]}\end{array}$ & $+/ *$ & + \\
\hline pr1da & $\begin{array}{l}0.19 \pm 0.02^{105} \\
{[0.14,0.25]}\end{array}$ & $\begin{array}{l}0.2 \pm 0.02^{95} \\
{[0.17,0.24]}\end{array}$ & $\begin{array}{l}0.21 \pm 0.01^{60} \\
{[0.19,0.23]}\end{array}$ & $\begin{array}{l}0.21 \pm 0.01^{10} \\
{[0.2,0.22]}\end{array}$ & - & $\begin{array}{l}0.2 \pm 0.01^{14} \\
{[0.18,0.21]}\end{array}$ & $+/^{*}$ & $+/ *$ \\
\hline prlche & $\begin{array}{l}0.22 \pm 0.02^{105} \\
{[0.17,0.28]}\end{array}$ & $\begin{array}{l}0.23 \pm 0.02^{95} \\
{[0.18,0.28]}\end{array}$ & $\begin{array}{l}0.23 \pm 0.02^{61} \\
{[0.21,0.27]}\end{array}$ & $\begin{array}{l}0.24 \pm 0.01^{10} \\
{[0.23,0.26]}\end{array}$ & $0.22^{1}$ & $\begin{array}{l}0.25 \pm 0.04^{14} \\
{[0.21,0.33]}\end{array}$ & + & + \\
\hline pr2pa & $\begin{array}{l}0.23 \pm 0.02^{104} \\
{[0.19,0.31]}\end{array}$ & $\begin{array}{l}0.25 \pm 0.02^{92} \\
{[0.2,0.29]}\end{array}$ & $\begin{array}{l}0.24 \pm 0.01^{59} \\
{[0.21,0.29]}\end{array}$ & $\begin{array}{l}0.26 \pm 0.01^{10} \\
{[0.23,0.28]}\end{array}$ & $0.21^{1}$ & $\begin{array}{l}0.24 \pm 0.01^{14} \\
{[0.21,0.26]}\end{array}$ & + & $+/ *$ \\
\hline pr2da & $\begin{array}{l}0.15 \pm 0.02^{104} \\
{[0.12,0.19]}\end{array}$ & $\begin{array}{l}0.16 \pm 0.02^{92} \\
{[0.13,0.19]}\end{array}$ & $\begin{array}{l}0.17 \pm 0.01^{59} \\
{[0.15,0.19]}\end{array}$ & $\begin{array}{l}0.18 \pm 0.01^{10} \\
{[0.17,0.19]}\end{array}$ & $0.15^{1}$ & $\begin{array}{l}0.16 \pm 0.01^{14} \\
{[0.14,0.18]}\end{array}$ & + & + \\
\hline pr2dplm & $\begin{array}{l}0.56 \pm 0.06^{104} \\
{[0.42,0.69]}\end{array}$ & $\begin{array}{l}0.55 \pm 0.05^{93} \\
{[0.44,0.67]}\end{array}$ & $\begin{array}{l}0.59 \pm 0.04^{59} \\
{[0.49,0.67]}\end{array}$ & $\begin{array}{l}0.58 \pm 0.05^{10} \\
{[0.49,0.64]}\end{array}$ & $0.65^{1}$ & $\begin{array}{l}0.59 \pm 0.02^{14} \\
{[0.55,0.63]}\end{array}$ & + & + \\
\hline
\end{tabular}

Continued on next page... 
Appendix B2. Continued.

\begin{tabular}{|c|c|c|c|c|c|c|c|c|}
\hline $\mathrm{MC}$ & $\begin{array}{l}\text { W- Slo } \\
\text { (T. planinensis) }\end{array}$ & $\begin{array}{l}\text { E-Slo } \\
\text { (T. a. } \\
\text { anophthalmus }+ \\
\text { T. a. ocellata }+ \\
\text { T. a. intermedia) }\end{array}$ & $\begin{array}{l}\text { Adriatic } \\
\text { (T. a. periadri- } \\
\text { atica) }\end{array}$ & $\begin{array}{l}\text { Soča } \\
(T . \text { a. sontica })\end{array}$ & $\begin{array}{l}\text { Istra } \\
(T . a . \\
\text { legovici) }\end{array}$ & T. bosnica & DFA 2 & DFA 3 \\
\hline \multirow[t]{2}{*}{ pr2pplm } & $0.85 \pm 0.03^{104}$ & $0.83 \pm 0.03^{93}$ & $0.85 \pm 0.03^{59}$ & $0.83 \pm 0.03^{10}$ & $0.90^{1}$ & $0.88 \pm 0.02^{14}$ & + & + \\
\hline & {$[0.75,0.92]$} & {$[0.76,0.9]$} & {$[0.79,0.9]$} & {$[0.79,0.87]$} & & {$[0.83,0.9]$} & & \\
\hline \multirow[t]{2}{*}{ pr3da } & $0.07 \pm 0.0199$ & $0.07 \pm 0.01^{91}$ & $0.08 \pm 0.01^{58}$ & $0.07 \pm 0.01^{10}$ & $0.08^{1}$ & $0.07 \pm 0.01^{11}$ & $+/ *$ & + \\
\hline & {$[0.06,0.09]$} & {$[0.05,0.09]$} & {$[0.07,0.09]$} & {$[0.06,0.08]$} & & {$[0.06,0.08]$} & & \\
\hline \multirow[t]{2}{*}{ pr5ia } & $0.09 \pm 0.01^{97}$ & $0.09 \pm 0.01^{93}$ & $0.1 \pm 0.01^{55}$ & $0.09 \pm 0.01^{10}$ & - & $0.08 \pm 0.01^{13}$ & + & \\
\hline & {$[0.06,0.11]$} & {$[0.08,0.11]$} & {$[0.07,0.12]$} & {$[0.08,0.11]$} & & {$[0.07,0.1]$} & & \\
\hline \multirow[t]{2}{*}{ pr5ma } & $0.29 \pm 0.01^{97}$ & $0.29 \pm 0.01^{93}$ & $0.29 \pm 0.01^{55}$ & $0.29 \pm 0.01^{10}$ & - & $0.31 \pm 0.01^{13}$ & $+/ *$ & $+/ *$ \\
\hline & {$[0.27,0.35]$} & {$[0.27,0.32]$} & {$[0.27,0.31]$} & {$[0.27,0.3]$} & & {$[0.3,0.33]$} & & \\
\hline \multirow[t]{2}{*}{ pr5pa } & $0.37 \pm 0.0197$ & $0.37 \pm 0.01^{93}$ & $0.36 \pm 0.01^{55}$ & $0.37 \pm 0.004^{10}$ & - & $0.35 \pm 0.01^{13}$ & + & + \\
\hline & {$[0.31,0.4]$} & {$[0.33,0.39]$} & {$[0.32,0.38]$} & {$[0.36,0.38]$} & & {$[0.32,0.37]$} & & \\
\hline \multirow[t]{2}{*}{ pr5da } & $0.08 \pm 0.01^{97}$ & $0.08 \pm 0.01^{93}$ & $0.09 \pm 0.01^{55}$ & $0.07 \pm 0.01^{10}$ & - & $0.08 \pm 0.01^{13}$ & + & $+/^{*}$ \\
\hline & {$[0.06,0.1]$} & {$[0.05,0.1]$} & {$[0.07,0.1]$} & {$[0.06,0.08]$} & & {$[0.07,0.09]$} & & \\
\hline \multirow[t]{2}{*}{ p5dp } & $0.22 \pm 0.02^{97}$ & $0.21 \pm 0.03^{93}$ & $0.25 \pm 0.02^{55}$ & $0.19 \pm 0.02^{10}$ & - & - & & \\
\hline & {$[0.16,0.29]$} & {$[0.14,0.28]$} & {$[0.17,0.29]$} & {$[0.16,0.22]$} & & & & \\
\hline \multirow[t]{2}{*}{ pr5imcpd } & $0.62 \pm 0.03^{97}$ & $0.63 \pm 0.02^{93}$ & $0.62 \pm 0.02^{55}$ & $0.62 \pm 0.02^{10}$ & - & $0.66 \pm 0.04^{13}$ & + & \\
\hline & {$[0.53,0.8]$} & {$[0.56,0.73]$} & {$[0.57,0.67]$} & {$[0.6,0.66]$} & & {$[0.58,0.72]$} & & \\
\hline \multirow[t]{2}{*}{ P5D } & $48.74 \pm 8.31^{97}$ & $45.37 \pm 6.25^{86}$ & $49.21 \pm 5.99^{52}$ & $35.9 \pm 2.96^{10}$ & - & $45.55 \pm 4.44^{11}$ & + & + \\
\hline & {$[25,74]$} & {$[23,61]$} & {$[39,62]$} & {$[31,40]$} & & {$[40,53]$} & & \\
\hline \multirow[t]{2}{*}{ pllenex } & $0.4 \pm 0.06^{103}$ & $0.39 \pm 0.07^{93}$ & $0.39 \pm 0.08^{60}$ & $0.36 \pm 0.07^{9}$ & $0.38^{1}$ & $0.28 \pm 0.06^{13}$ & $+/ *$ & \\
\hline & {$[0.24,0.54]$} & {$[0.24,0.56]$} & {$[0.21,0.53]$} & {$[0.26,0.45]$} & & {$[0.21,0.44]$} & & \\
\hline \multirow[t]{2}{*}{ pl2aicl } & $0.12 \pm 0.01^{104}$ & $0.12 \pm 0.02^{93}$ & $0.12 \pm 0.01^{60}$ & $0.1 \pm 0.01^{10}$ & - & $0.13 \pm 0.02^{14}$ & + & + \\
\hline & {$[0.09,0.16]$} & {$[0.1,0.17]$} & {$[0.09,0.15]$} & {$[0.09,0.12]$} & & {$[0.1,0.16]$} & & \\
\hline \multirow[t]{2}{*}{$\mathrm{s} 56 \mathrm{cl}$} & $0.79 \pm 0.05^{106}$ & $0.78 \pm 0.05^{94}$ & $0.85 \pm 0.05^{61}$ & $0.78 \pm 0.03^{10}$ & - & $0.84 \pm 0.06^{14}$ & $+/ *$ & $+/ *$ \\
\hline & {$[0.67,0.95]$} & {$[0.65,0.91]$} & {$[0.73,0.97]$} & {$[0.71,0.8]$} & & {$[0.76,0.98]$} & & \\
\hline \multirow[t]{2}{*}{ te1s56 } & $0.62 \pm 0.04^{91}$ & $0.64 \pm 0.04^{84}$ & $0.59 \pm 0.03^{55}$ & $0.64 \pm 0.03^{9}$ & - & $0.64 \pm 0.08^{12}$ & + & + \\
\hline & {$[0.51,0.72]$} & {$[0.53,0.78]$} & {$[0.54,0.63]$} & {$[0.62,0.71]$} & & {$[0.51,0.74]$} & & \\
\hline \multirow[t]{2}{*}{ te $1 \mathrm{cl}$} & $0.48 \pm 0.03^{91}$ & $0.5 \pm 0.03^{85}$ & $0.49 \pm 0.03^{55}$ & $0.5 \pm 0.03^{9}$ & $0.48^{1}$ & $0.54 \pm 0.1^{12}$ & + & $+/ *$ \\
\hline & {$[0.4,0.57]$} & {$[0.41,0.6]$} & {$[0.43,0.55]$} & {$[0.47,0.55]$} & & {$[0.4,0.72]$} & & \\
\hline \multirow[t]{2}{*}{ tes $2 \mathrm{cl}$} & $0.13 \pm 0.02^{92}$ & $0.14 \pm 0.02^{86}$ & $0.12 \pm 0.01^{55}$ & $0.13 \pm 0.01^{9}$ & $0.12^{1}$ & $0.15 \pm 0.03^{13}$ & $+/ *$ & $+/ *$ \\
\hline & {$[0.09,0.18]$} & {$[0.09,0.18]$} & {$[0.09,0.16]$} & {$[0.12,0.14]$} & & {$[0.11,0.2]$} & & \\
\hline \multirow[t]{2}{*}{ tes 2 tes 1} & $0.65 \pm 0.09^{90}$ & $0.71 \pm 0.09^{86}$ & $0.56 \pm 0.07^{55}$ & $0.79 \pm 0.07^{9}$ & $0.68^{1}$ & $0.65 \pm 0.11^{13}$ & $+/ *$ & $+/ *$ \\
\hline & {$[0.47,0.9]$} & {$[0.47,0.94]$} & {$[0.43,0.7]$} & {$[0.69,0.89]$} & & {$[0.49,0.87]$} & & \\
\hline \multirow[t]{2}{*}{$\mathrm{u} 2 \mathrm{cl}$} & $0.18 \pm 0.02^{101}$ & $0.17 \pm 0.02^{92}$ & $0.2 \pm 0.02^{61}$ & $0.16 \pm 0.01^{10}$ & $0.18^{1}$ & $0.2 \pm 0.03^{14}$ & + & + \\
\hline & {$[0.13,0.24]$} & {$[0.14,0.22]$} & {$[0.16,0.24]$} & {$[0.14,0.16]$} & & {$[0.16,0.26]$} & & \\
\hline \multirow[t]{2}{*}{$\mathrm{u} 21$} & $0.34 \pm 0.03^{101}$ & $0.33 \pm 0.02^{92}$ & $0.37 \pm 0.02^{61}$ & $0.31 \pm 0.01^{10}$ & $0.30^{1}$ & $0.34 \pm 0.02^{14}$ & $+/ *$ & $+/ *$ \\
\hline & {$[0.26,0.4]$} & {$[0.28,0.37]$} & {$[0.32,0.43]$} & {$[0.29,0.33]$} & & {$[0.31,0.36]$} & & \\
\hline \multirow[t]{2}{*}{ u1s56 } & $0.68 \pm 0.05^{101}$ & $0.68 \pm 0.05^{91}$ & $0.64 \pm 0.03^{61}$ & $0.64 \pm 0.03^{10}$ & - & $0.7 \pm 0.07^{14}$ & $+/ *$ & + \\
\hline & {$[0.56,0.79]$} & {$[0.57,0.8]$} & {$[0.56,0.73]$} & {$[0.61,0.71]$} & & {$[0.6,0.84]$} & & \\
\hline \multirow[t]{2}{*}{ ulte1 } & $1.1 \pm 0.07^{87}$ & $1.07 \pm 0.06^{83}$ & $1.08 \pm 0.06^{55}$ & $1 \pm 0.05^{9}$ & $1.17^{1}$ & $1.12 \pm 0.05^{12}$ & $+/ *$ & $+/ *$ \\
\hline & {$[0.97,1.3]$} & {$[0.93,1.22]$} & {$[0.98,1.21]$} & {$[0.91,1.07]$} & & {$[1.06,1.19]$} & & \\
\hline
\end{tabular}


Appendix C. A list of cave shrimps Troglocaris s. str. examined.

A list of cave shrimps Troglocaris s. str., with morphometric and molecular examination, or morphometric examination only. Each sample is denoted by the brief description of the locality, followed by sample dessignation, composed of a two letters denoting country (SI: Slovenia; HR: Croatia; IT: Italy; BA: Bosnia and Hercegovina), dash, and two additional letters, denoting sample/locality name, and a serial number of a specimen (as on the original labels). In the same running order, those dessignations are followed by voucher numbers, composed of letters »TA« or »TB«plus three digit number (a vaucher number of the holotype male of T. (T.) a. legovici ssp. nov., that is stored in Hrvatski prirodoslovni muzej, Croatia, is 1770). All specimens, analyzed molecularly, can be found at GenBank database (Zakšek et al. 2007; Sket and Zakšek 2009; Zakšek et al. 2009). All localities where molecularly analyzed (COI, ITS2 and/or16S RNA sequences) specimens are from (not necessarily included in the present study), are denoted with asterisk (*). After each voucher number, GenBank accesion numbers for COI gene are added in parentheses (in italics), where analyzed. Type and neotype material is added to the type localities, which are denoted with $» \mathrm{~T} \ll$. If not noted otherwise, all specimens are preserved in $70 \%$ ethanol. Male specimens are denoted with bold printing, specimens of unknown gender denoted in the text. In toponymes, »grotta«, »cavernetta«, »jama«, »pećina«, »špilja« mean »cave«, and »brezno« means »abyss«. Samples including specimens with eye pigment are denoted with plus $\left({ }^{+}\right)$.

Appendix C1. Troglocaris (Troglocaris) anophthalmus anophthalmus (E-Slo1 subgroup):

- Grosuplje, Luče, Luška jama: SI-LČ 1: TA615.

_ *Stična, Šimenkovo brezno: SI-ŠI 1-7: TA296 (FJ426022), TA297, TA298 (FJ426023), TA616, TA617, TA618, TA619.

- Krka, Krška jama: SI-KK 1-12: TA620, TA621, TA622, TA623, TA624, TA625, TA626, TA627, TA628, TA629, TA630, TA631.

- *Krka, jama Poltarica: SI-PL 1: TA744.

- *Videm-Dobrepolje, Podpeč, Podpeška jama: SI-PO 1-6: TA274 (FJ426016), TA275, TA276, TA632, TA633, TA634.

- *Videm-Dobrepolje, Kompolje, Kompoljska jama (T): SI-KO 1-6: TA277 (FJ425967), TA375, TA376, TA377 (FJ425968), TA635, TA636. Neotype sample: Neotype, TA965. Two paratypes $\left(96 \%\right.$ ethanol, $\left.-20^{\circ} \mathrm{C}\right)$ : TA966, TA977. Eight females, TA975, TA976, TA978, TA979, TA980, TA981, TA982; TA989 (96\% etanol, -20C)

- Videm-Dobrepolje, Kompolje, jama Potiskavec: SI-PT 1-2: TA637, TA638.

- *Žužemberk, Dvor, Černičkova jama: SI-ČR 1-4: TA290 (FJ425947), TA291, TA292 (FJ425948), TA293.

- Žužemberk, Dvor, Bobnova jama: SI-BO 1: TA639.

- *Novo mesto, Jama v Luknji: SI-LU 1-6: TA310 (FJ425979), TA378, TA379 (FJ425980), TA380 (FJ425981), TA640, TA641. SI-LU 10-12: TA642, TA643, TA644.

- *Ribnica, Dolenja vas, jama Mobišaht (=Mobi brezno v Vrtačah): SI-RI 1-7: TA231, TA232, TA233, TA234 (FJ425997), TA235, TA645, TA646.

- *Kostel, Žaga, Jelovička jama: SI-ŽA 1-9: TA249 (FJ425922), TA250, TA251 (FJ425923), TA252, TA253, TA651, TA652, TA653, TA654.

T. (T.) a. anophthalmus?

- Kočevje, Polom, jama Ebental: SI-EB 1-2: TA647, TA648.

- Kočevje, cave near river Kolpa (exact data unknown): SI-KP 1-2: TA649, TA650.

Appendix C2. Troglocaris (Troglocaris) anophthalmus ocellata (pigment in the eyes is partly corresponding to the E-Slo2 subgroup):

- *+Črnomelj, Vranoviči, jama Šuline 1: SI-ŠA 1-5: TA455, TA456, TA457, TA742, TA743.

- ${ }^{*+}$ Črnomelj, Pavičiči, Jelenja jama: SI-JJ 1-2: TA464, TA465.

- * ${ }^{+}$Crnomelj, Jelševnik, on the meadow, middle spring: SI-JE 1-3: TA236 (FJ425955), TA237 (FJ425956), TA238; spring left from Obrh: SI-ČN 1-7: TA665, TA666, TA667, TA668, TA669, TA670, TA671.

- ${ }^{+}$Dragatuš, Mali Nerajec, jama Djud: SI-MN 1-10: TA672, TA673, TA674, TA675, TA676, TA677, TA678, TA679, TA680, TA681.

- *+Vinica, Jama v kamnolomu (T): Type sample: holotype, TB046; three other males: TB045, TB047, TB048; two females: TB049, TB050 (all in $70 \%$ ethanol). Other specimens: SI-VI 1-23: TA244 (FJ426030), TA245 (FJ426031), TA246, TA247, TA248, TA682, TA683, TA684, TA685, TA686, TA687, TA688, TA689, TA690, TA691, TA692, TA693, TA694, TA695, TA696, TA697, TA698, TA699.

- *+Špeharji, Breg, jama Kobiljača: SI-KB 1-2: TA700, TA701. SI-KB 5-6: TA702, TA703.

- ${ }^{*+}$ Rakovica, Vaganac, Kukuruzovića pećina: HR-KU 1-9: TA278, TA279, TA280, TA281, TA282, TA332 (FJ425978), TA739, TA740, TA741.

- *Črnomelj, jama Stobe: SI-ST 1-4: TA300 (FJ426025), TA655, TA656, TA657.

T. (T.) a. ocellata?

- Črnomelj, Žopenca/Gadina jama: SI-ŽO 1-7: TA658, TA659, TA660, TA661, TA662, TA663, TA664 (according to Sket (1985) specimens from this locality have pigmented eyes; however not a single specimen with this character state was found in our samples). 
Appendix C3. Troglocaris (Troglocaris) anophthalmus intermedia

_ *Tounj, Mikašinovići, Mikašinovića pećina (T): HR-MI 1-29: TA294 (FJ426041), TA295 (FJ426042), TA712, TA713, TA714, TA715, TA716, TA717, TA718, TA719, TA720, TA721, TA722, TA723, TA724, TA725, TA726, TA727, TA728, TA729, TA730, TA731, TA732, TA733, TA734, TA735, TA736, TA737, TA738.

T. (T.) a. intermedia?

- Ogulin, Privis pećina: HR-PV 1-5: TA704, TA705, TA706, TA707, TA708.

- Slunj-Tounj, spring Rudnica (zgornja jama): HR-RU 1-3: TA709, TA710, TA711.

Appendix C4. Troglocaris (Troglocaris) anophthalmus periadriatica (Adriatic phylogroup)

- *Otočac, Podum, Pećina Sv. Marko: HR-OT 1-20: TA745, TA746, TA747, TA748, TA749, TA750, TA751, TA752, TA753, TA754, TA755, TA756, TA757, TA758, TA759, TA760, TA761, TA762, TA763, TA764.

- Seline, Markova jama: HR-SE 1-2: TA765, TA766.

- *Obrovac, Karin, Karišnica: HR-KA 1-6: TA335, TA336, TA337, TA767, TA768, TA769.

- island Ugljan, Čeprljanda, spring (since the population is distributed on the border of the Troglocaris s. str. distribution area, we fell obliged to emphasise that the designation was done according to morphological data only): HR-UG 1-2: TA770, TA771.

- *Šibenik, Pirovac, jama Bikovica: HR-BI 1-18: TA239 (FJ425918), TA240 (FJ425919), TA241, TA242, TA243 (FJ425920), TA772, TA773, TA774, TA775, TA776, TA777, TA778, TA779, TA780, TA781, TA782, TA783, TA784.

- *Pirovac, spring near Pirovac: HR-PI 1-3: TA311 (FJ426006), TA312 (FJ426007), TA313.

- Šibenik, under hydroelectric power station Manojlovac; spring-cave, river Krka: HR-KK 1-3: TA785, TA786, TA787.

- Šibenik, jama Rasline, river Krka: HR-RS 1-2: TA788, TA789.

- *Šibenik, Mandalina špilja: HR-MA 1-4: TA305 (FJ425982), TA306 (FJ425983), TA307 (FJ425984), TA308 (gender unknown). HR-MA 5-9: TA309 (FJ425985), TA790, TA791, TA792, TA793.

- Split, Dugo polje, Đuderina pećina: HR-ĐU 1-3: TA822, TA823, TA824.

- *Island Brač, Postira, Jama na Dučacu, HR: FJ425921 (gender unknown, from Zakšek et al. 2009).

- *Pelješac, Špilja kod Jurjevića, cave Pelješac, HR: FJ426005 (gender unknown, from Zakšek et al. 2009)

- *Popovo polje, Zavala, izvir Lukavac: BA-LU 1: TA299.

- *Popovo polje, Čvaljina, Baba pećina: BA-BA 1-2: TA303, TA304.

- *Popovo polje, Zavala, jama Vjetrenica (T): Type sample: BA-VJ 1: TA794. BA-VJ 5-7: TA795, TA796, TA797. BA-VJ 11-14: TA798, TA799, TA800, TA801. TA063 (= Tgc_63-Vjetrenica; Sket and Zakšek 2009).

- Mokro polje,Trebinje, Čičevo, under Velja gora mountain, Šumet pećina: BA-ŠP 1-5: TA802, TA804, TA806, TA808, TA809. BA-ČI 1-3: TA803, TA805, TA807. BA-ŠU 1-10: TA810, TA811, TA812, TA813, TA814, TA815, TA816, TA817, TA818, TA819.

- Mokro polje, Trebinje, jama Vučonica: BA-VU 1-2: TA820, TA821.

Appendix C5. Troglocaris (Troglocaris) anophthalmus sontica (Soča phylogroup)

- *Most na Soči, jama Vogršček: SI-VO 1-3: TA314 (FJ426035), TA315 (FJ426036), TA316 (gender unknown). SI-VO6-11: TA825, TA826, TA827, TA828, TA829, TA830.

- *Vipava, Vipavska jama (T): SI-IV 1: TA831. SI-VJ 1-4: TA381 (FJ426032), TA382, TA383, TA832. SI-VJ 10-24: TA833, TA834, TA835, TA836, TA837, TA838, TA839, TA840, TA841, TA842, TA843, TA844, TA845, TA846, TA847. Type sample: Six males: TA983, TA984, TA985, TA986, TA987, TA988. Five females (96 \% etanol, -20C): TA990, TA991, TA992, TA993, TA994.

- *Gradisca, Pozzo dei Frari: IT-FR 1: TB061 (gender unknown)

- *Monfalcone/Tržič, Grotta Nevio: IT-NE 1-5: TB072, TB073 (sequenced, not yet publ.), TB074 (sequenced, not yet publ.), TB075 (gender unknown), TB076 (sequenced, not yet publ.).

Appendix C6. Troglocaris (Troglocaris) anophthalmus legovici (Istra putative phylogroup)

- *Labin, Kršan, springs in the tunnel Čepić: TA0033 (COI: DQ641552; ITS2: FJ426103)

- *Pula, Nimfej, spring (T): HR-NI 1-3: TB082 (sequenced, not yet publ.), 1770 (holotype, stored in Hrvatski prirodoslovni muzej, Zagreb, Croatia; sequenced, not yet publ.), TB084.

- * Opatija, rudnik, AC Medveja, HR: TB056 (juvenile, sequenced, not yet publ.).

- *Vrsar, Klarića jama, HR: 1 specimen (COI: FJ426038; ITS2: FJ426101).

Appendix C7. Troglocaris (Troglocaris) planinensis (W-Slo phylogroup):

- *Iamiano/Jamlje, Comarie/Komarje, jama pri Komarjih (cavernetta Presso Comarie): IT-CO 1-8: TA220 (FJ425926),TA221 (FJ425927), TA222 (FJ425928), TA223 (FJ425929), TA224 (FJ425930), TA461, TA462, TA463.

- *Gorizia/Gorica, Doberdo/Doberdob, Grotta Andrea: IT-AN 1-5: TB062, TB063, TB064 (gender unknown), TB065 (gender unknown), TB066 (gender unknown) - all sequenced, not yet published.

- *Duino/Devin, brezno pri Devinu (pozzo presso S. Giovanni di Duino): IT-DU 1-8: TA225 (FJ425936), TA226 (FJ425937), 
TA227 (FJ425938), TA228, TA229, TA458, TA459, TA460.

- *Trieste/Trst, Trebiciano/Trebče, Grotta di Trebiciano/Labodnica: IT-LA 1-13: TA215, TA216, TA217, TA218, TA219, TA505, TA506, TA507, TA508, TA509, TA510, TA511, TA512.

- *Rosandra/Glinščica, izviri pri Fonte Oppia: IT-GL 1-5: TA283 (FJ425950), TA284. (FJ425951), TA285 (FJ425952), TA286 (FJ425953), TA287 (FJ425954).

- *Rosandra/Glinščica, jama Antro delle Ninfe/Spodmol nimf: IT-SN 1-3:TA288, TA289, TA513.

- *Komen, Brestovica, Dolenca jama: SI-DO 1-12: TA210, TA211, TA212 (FJ425964), TA213, TA214, TA514, TA515, TA516, TA517, TA518, TA519, TA520.

- *Divača, Kačna jama, Ogabno jezero lake: SI-KA 1-11: TA205 (FJ425957), TA206 (FJ425958), TA207, TA208, TA209 (FJ425959), TA521, TA522, TA523, TA524, TA525, TA526.

- *Divača, Kačiče, cave Mejame: SI-ME 1-10: TA259, TA260 (FJ425990), TA261 (FJ425991), TA262, TA263 (FJ425992), TA527, TA528, TA529, TA530, TA531.

- *Koper, Osp, Osapska jama: SI-OS 1-10: TA532, TA533, TA534, TA535, TA536, TA537, TA538, TA539, TA540, TA541.

- *Kozina, Ocizla, Ocizelska jama: SI-OC 1-4: TA466, TA467, TA468, TA614.

- *Materija, Odolina, Ponikve v Odolini (jama): SI-OD 1-5: TA365, TA366 (FJ426003), TA367, TA368, TA369.

- *Sočerga, Jama pod Krogom: SI-KR 1-14: TA254, TA255 (FJ426020), TA256, TA257, TA258, TA542, TA543, TA544, TA545, TA546, TA547, TA548, TA549, TA550.

- Logatec, jama Gradišnica: SI-GR 1: TA551.

- *Planina, Planinska jama (T), river Pivka: SI-PI 1-7: TA200 (FJ426008), TA201 (FJ426009), TA202 (FJ426010), TA203, TA204 (FJ426011), TA552, TA553. Neotype sample: Three males: TA972, TA973, TA974. Three females: TA969, TA970, TA971.

- *Planina, Planinska jama (T), river Rak: SI-RA 1-5: TA195 (FJ426013), TA196 (FJ426014), TA197 (FJ426015), TA554, TA555.

- *Planina, jama Škratovka: SI-ŠK 1-3: TA384, TA385, TA386.

- *Planina, Laze, Najdena jama: SI-NA 1-15: TA370 (FJ425998), TA371 (FJ425999), TA372, TA373 (FJ426000), TA374, TA556, TA557, TA558, TA559, TA560, TA561, TA562, TA563, TA564, TA565.

- Rakek, Laze, jama Logarček: SI-LO 1-7: TA566, TA567, TA568, TA569, TA570, TA571, TA572.

- Rakek, Laze, jama Erjavščica: SI-ER 1-3: TA573, TA574, TA575.

- Postojna, Črna jama, river Pivka: SI-ČJ 1: TA576.

- Postojna, Pivka jama: SI-PJ 1: TA577.

- Postojna, Postojnska jama, Tartar: SI-TA 1-3: TA578, TA579, TA580.

- *Postojna, Sajevče, jama Markov spodmol: SI-MA 1-11: TA317, TA318 (FJ425986), TA319, TA320 (FJ425987), TA321, TA581, TA582, TA583, TA584, TA585, TA586.

- *Postojna, Slavina, Vodna jama v Lozi: SI-LZ 1-13: TA587, TA588, TA589, TA590, TA591, TA592, TA593, TA594, TA595, TA596, TA597, TA598, TA599.

- *Pivka, Parje, Jama v Mlaki: SI-ML 1-5: TA322, TA323, TA324 (FJ425996), TA325, TA600.

- *Šembije, Podtabor, Kozja luknja (jama): SI-KL 1-7: TA333 (FJ425969), TA334 (FJ425970), TA601, TA602, TA603, TA604, TA605.

- *Ilirska Bistrica, Novokračine, Novokrajska jama: SI-NO 1-12: TA264, TA265, TA266, TA267, TA268, TA606, TA607, TA608, TA609, TA610, TA611, TA612.

- *Labin, Kršan, springs in the tunnel Čepić: HR-KR 1-13: TA301 (FJ425971), TA302 (FJ425972), TA359, TA360, TA361, TA362, TA363, TA364, TA387 (FJ425973), TA388 (FJ425974), TA389 (FJ425975), TA390, TA391 (FJ425976).

- Labin, Raša, izvir pri Raši: HR-RA 1: TA613.

- *Poreč, Pincinova pećina: HR-PO 1-4: TA0848, TA0849, TA0850, TA0851. A sample sequenced, not yet publ.

- Novi Vinodolski, Sušička jama: HR-NV 1-4: TA959, TA960, TA961, TA962.

- *Crikvenica, HR: TB092 (juvenile, sequenced, not yet publ.)

- *Pula, Vodnjan, Galižana: HR-GA 1-2: TA967, TA968. Sequenced, not yet publ.

Troglocaris (Troglocaris) planinensis/T. (Troglocaris) anophthalmus legovici?

- Poreč, Funtana, captive spring: HR-FU 1-4: TA0852, TA0853, TA0854, TA0855.

Appendix C8. Troglocaris (Troglocaris) bosnica

- *Sanski Most, Dabar, jama Dabarska pećina: BA-DA 1: TA869.

- *Sanski Most, Lušci Palanka, Suvaja pećina (T): BA-SU 1-18: TA269, TA270, TA271, TA272, TA273, TA856, TA857, TA858, TA859, TA860, TA861, TA862, TA863, TA864, TA865, TA866, TA867, TA868.

\section{Appendix D}

Differential description of discriminative characters for Troglocaris (Troglocaris) anophthalmus anophthalmus males and females (for comparison with the differential descriptions of other taxa). Characters included in the differential 
descriptions are the same as proven to be most discriminative in DFA analyses for T. (T.) anophthalmus - E-Slo phylogroup as a whole (incl. T. (T.) a. anophthalmus, T. (T.) a. intermedia, T. (T.) a. ocellata ssp. nov.).

Males (average values \pm SD and [min, max values] presented; see also Appendix C1): Large specimens, CL: 6.6 \pm 0.5 mm [5.3, $7.6 \mathrm{~mm}$ ]. Rostrum length and dentition variable, when rostrum longer than $45 \%$ of CL, generally curved upwards. Article 3 of antenna I rather long (a13a12): its length $56 \pm 5 \%$ [48, $65 \%]$ of article 2 length. Antenna II scaphocerite rather wide (a2s2s1): its width $36 \pm 2 \%$ [31, 39\%] of scaphocerite length. Pereopod I article 7 long (pr1da): its length $21 \pm 1 \%$ [19, $25 \%]$ of pereopod I length, and pereopod III article 7 short (pr3da): its length $10 \pm 2 \%$ [5, $12 \%$ of pereopod III length. Pereopod I article 6 of medium length (prlche): its length $23 \pm 1 \%$ [21, 26\%] of CL. Uropod exopodite of medium width (u21, u2cl): its width $32 \pm 1 \%$ [29, $34 \%]$ of uropod exopodite length, and 19 $\pm 1 \%$ [16, $21 \%]$ of CL (however, narrower than in T. (T.) planinensis). Pereopod V article 7 of medium length (p5dp): its length $22 \pm 2 \%$ [19, $25 \%$ ] of pereopod V article 6 length. Telson long (te1s6): its length $99 \pm 6 \%[85,109 \%]$ of pleonite VI length. Adult males generally without or with a single retinacular hook on appendix interna of pleopod I endopodite. Females (for E-Slo as a whole; average values $\pm \mathrm{SD}$ and [min, max values] presented; see also Appendix C2): Large specimens, CL: $7.4 \mathrm{~mm} \pm 0.8 \mathrm{~mm}$ [5.8, 9.0 $\mathrm{mm}]$. Rostrum length and dentition variable, when long, generally curved upwards. Article 3 of antenna I rather long (a13a12): its length $52 \pm 7 \%$ [41, $67 \%$ ] of article 2 length. Antenna II scaphocerite of medium width (a2s $2 \mathrm{~s} 1$, a2s $2 \mathrm{cl}$ ): its width $35 \pm 2 \%$ [31, $42 \%]$ of scaphocerite length, and $18 \pm 2 \%$ [15, $23 \%]$ of CL. Pereopod I article 7 long (pr1da): its length $20 \pm 2 \%$ [16, $24 \%$ ] of pereopod I length, and pereopod II article 7 long (pr2da): its length $16 \pm 1 \%$ [13, $18 \%$ ] of pereopod II length; maximal length of chelae (article 6) of medium length (pr2che): its length $23 \pm 2 \%$ [19, $28 \%$ ] of CL. Proximal articles of chelate pereopods rather short, i.e. article 4 of pereopod I (pr1ma) length $24 \pm 2 \%$ [21, $28 \%$ ] of pereopod I length, and article 5 of pereopod II (pr2ccl) length $25 \pm 3 \%$ [19, 32\%] of CL. Pereopod V article 7 of medium length (p5dp): its length $20 \pm 2 \%$ [15, $24 \%]$ of pereopod V article 6 length. Pleonites V-VI rather short (s56cl): their length $77 \pm 5 \%[65,91 \%]$ of CL. Telson of medium length (te1cl): its length $50 \pm 3 \%$ [43, $60 \%]$ of CL; however to pleonites V-VI, telson length rather large (te1s56), i.e. $64 \pm 4 \%$ [53, $73 \%$ ] of pleonites V+VI length. Telson weakly tapered distally (tes2tes1), its distal width $67 \pm 9 \%$ [47, 92\%] of its proximal width. Males and females (see also Table 1): The number of spiniform setae on pereopod III article 3 along its inferior margin and at inferodistal angle 1-5, but in more than $85 \%$ with 3 or less. 